Report No. BMI-1454

UC-25 Metallurgy and Ceramics (III-4500, 15 th Ed.)

Contract No. W-7405-eng-92

PREPARATION AND EVALUATION OF ALUMINUM-35

W/O URANIUM ALIOYS CONT AINING UP TO

3 w/O TIN OR ZIRCONIUM

by

Norman E. Daniel

Ellis L. Foster, Jr.

Ronald $\bar{F}$. Dickerson

July 29, 1960

BATTELLE MEMORIAL INSTITUTE

505 King Avenue

Columbus 1, Ohio 


\section{DISCLAIMER}

This report was prepared as an account of work sponsored by an agency of the United States Government. Neither the United States Government nor any agency Thereof, nor any of their employees, makes any warranty, express or implied, or assumes any legal liability or responsibility for the accuracy, completeness, or usefulness of any information, apparatus, product, or process disclosed, or represents that its use would not infringe privately owned rights. Reference herein to any specific commercial product, process, or service by trade name, trademark, manufacturer, or otherwise does not necessarily constitute or imply its endorsement, recommendation, or favoring by the United States Government or any agency thereof. The views and opinions of authors expressed herein do not necessarily state or reflect those of the United States Government or any agency thereof. 


\section{DISCLAIMER}

Portions of this document may be illegible in electronic image products. Images are produced from the best available original document. 
TABLE OF CONTENTS

Page

ABSTRACT ........................... 1

INTRODUCTION .......................... . . . . . . 1

ALIOY PREPARATION . . . . . . . . . . . . . . . . . . 2

Melting, Casting, and Evaluation of Cast Material . . . . . . . . 2

Fluidity Tests . . . . . . . . . . . . . . . . . . . 9

EXTRUSION STUDIES ......................... . 9

EVALUATION OF EXTRUDED ALLOYS . . . . . . . . . . . . . . II

Metallographic Examination . . . . . . . . . . . . . . II

Hot Hardness . . . . . . . . . . . . . . . . . . 17

Tensile Tests . . . . . . . . . . . . . . . . . . . 21

Corrosion Tests . . . . . . . . . . . . . . . . . . 21

Creep-Rupture Tests . . . . . . . . . . . . . . . . . 25

CONCLUSIONS . . . . . . . . . . . . . . . . . . . 25

REFERENCES. . . . . . . . . . . . . . . . . 28 


\title{
PREPARATION AND EVALUATION OF ALUMINUM-35 W/O URANIUM ALLOYS CONTAINING UP TO 3 W/O TIN OR ZIRCONIUM
}

Norman E. Daniel, Ellis I. Foster, Jr., and Ronald $F$. Dickerson

\begin{abstract}
The effects of ternary additions of up 203 w/o tin or zirconiun to the aluminum 35 w/o uranium extrusion alloy were evaluated on the basis of casting characteristics, $\mathrm{UAl}_{3}$ retention, extrusion behavior, mechanical properties, and corrosion resistance.

Both additions increased the puidity of the alloy, and both promoted retention of $\mathrm{UAl}_{3}$. The best fluidity was obtained by a 2 w/o tin addition, while zirconium was the more effective stabilizer of $\mathrm{UAl}_{3}$.

The retention of $\mathrm{UAl}_{3}$ decreased the extrusion pressure needed for fabrication and caused a corresponding decrease in lensile and creep-rupture properties. Reductions in sirength were mosi noticeable at elevated temperatures. The 1000-hr stress-rupture strength of the binary alloy at $200 \mathrm{C}(8300 \mathrm{psi})$ was approximately 25 and 11 per cent higher, respecively, than the alloys containing $3 w / 0$ tin (6200 psi) and $3 w / 0$ zirconium (7400 psi).
\end{abstract}

The additions either slightly improved or had no effect upon the re. sistance of the aluminum-35w/o uranium alloy in $150 \mathrm{C}$ demineralized water.

\section{INTRODUCTION}

Aluminum-uranium alloys were among the first dispersion-type materials to find widespread acceptance as a reactor fuel, and today these alloys are the most commonly used fuel for low-temperature, water-cooled, water-moderated reactors. Primarily responsible for the widespread use of these alloys for reactor fuels are the properties of the aluminum matrix, such as ease of fabrication, good corrosion resistance in lowtemperature water, good thermal conductivity, and low neutron cross section.

A current reactor concept envisions the use of aluminum-uranium alloys containing up to $35 \mathrm{w} / 0$ uranium in the form of tubular fuel elements clad inside and outside with aluminum. Such fuel elements have been successfully fabricated from aluminumuranium alloys containing lesser quantities of uranium. However, when the uranium content is increased, casting and fabricating problems are intensified. The increased uranium content raises the liquidus temperature of the melt, thereby increasing the freezing range through which the melt must cool. This increases the gravitational segregation tendencies in the alloys, which are composed of phases with large density differences. The increased uranium content also decreases the volume of ductile matrix in the alloys and seriously impairs the fabrication of cast shapes. 
Since coextrusion is the most desirable method of fabricating these fuel elements, it is necessary that the cast material be essentially homogeneous from end to end and that it possess extrusion characteristics approximating those of the cladding. One possible method of improving the fabricating characteristics of aluminum-uranium alloys is to increase the amount of ductile matrix present in the cast shapes. Previous investigations have shown that certain ternary additions to the alloy will inhibit the UAl3-toUAl4 transformation which occurs in the binary system. (1-3) Among the additions which are known to inhibit this transformation are tin and zirconium. It has been noted that these additives also tend to improve the casting characteristics of the aluminum-35 w/o uranium alloy by increasing the fluidity of the molten metal and by decreasing the segrem gation tendencies. However, before these elements can be added to the reactor fuel it is necessary to ascertain their effects on the corrosion resistance and the mechanical properties of the aluminum- $35 \mathrm{w} / 0$ uranium alloy.

To obtain information concerning the properties of fabricated alloys containing these additions and to attempt to secure a more complete delineation of the effects of these additions and of process variables in the formation of sound, homogeneous castings of the fuel material, the program reported berein was initiated. In the investigation, cast aluminum-35 w/o uranium alloys containing up to 3 w/o of tin or zirconium were prepared by air or vacuum melting. The extrusion behavior of these cast alloys was studied. Finally, corrosion and various mecbanical-property data were obtained on the fabricated alloys.

\section{ALIOY PREPARATION}

Melting, Casting, and Evaluation of Cast Material

The first phase of the program was concerned with the preparation of alloys containing nominal $0.5,1,1.5,2$, and $3 \mathrm{w} / 0$ tin or zirconium additions to the binary aluminum-35 w/o uranium alloy and an evaluation of the effects of these additions on the fluidity of the melts. Since the normal practice used in the production of aluminumuranium alloys employs melting in air, efforts were made to prepare all of the alloys in this manner. High-purity aluminum (99.95t) and reactor-grade uranium were used; the tin additions were made from $\mathrm{cp}$ stick tin; and the zirconium used was iodide crystalbar material which had been fabricated cold and pickled in 50:50 $\mathrm{HNO}_{3}$ and water.

Preliminary estimates of the quantity of materials of each composition necessary for the contemplated evaluations indicated that melts of $14 \mathrm{lb}$ of each alloy would be sufficient. Since the available extrusion equipment was capable of accepting a $3-$ in. $_{\text {. }}$ diameter ingot and since it was desirable to have a machined ingot surface for canning in aluminum, graphite molds with cavities 3 in. in diameter by 12 in. long were used. This permitted the removal of $1 / 4 \mathrm{in.}$ from the diameter of the ingot prior to inserting it into an aluminum can with $1 / 8-$ in. walls. The mold configuration is shown in Figure 1. The massive bottom of the mold was designed to provide a heat sink for the cast material and thus to promote semidirectional solidification. Prior to casting, the molds were outgassed at $740 \mathrm{C}$ for approximately $2 \mathrm{hr}$.

(1) References at end. 


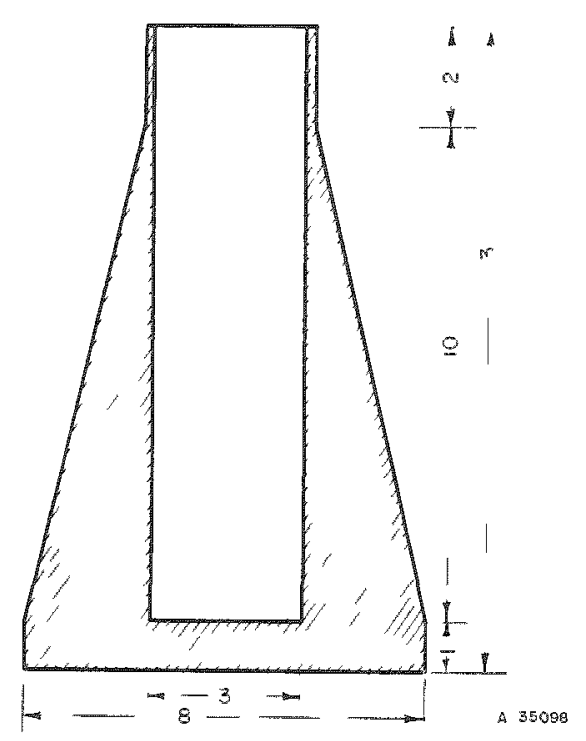

FIGURE 1. CONFIGURATION OF GRAPHITE MOID USED IN THIS STUDY

The massive bottom was designed to promote directional solidification.

The melting cycle used to produce both the tin- and zirconium-bearing ingots differed only in the temperature at which the particular addition was introduced into the melt. The initial attempts to introduce zirconium into the melt showed that considerable time was necessary for its complete solution even when it was in the form of $1 / 4-\mathrm{in}$. cubes. Therefore, the zirconium was added to the melt at the same time as the uranium, $i_{0} e_{0}$, at $1000 \mathrm{C}$. The tin was not added to the melt until approximately $5 \mathrm{~min}$ before pouring. The melt cycle used to produce the tin-containing alloys was as follows:

(1) Melt the aluminum under a protective helium atmosphere.

(2) Increase the aluminum temperature to $1000 \mathrm{C}$ and add one-half of the uranium.

(3) Hold the temperature at 1000 to $1050 \mathrm{C}$ and stir intermittently until the uranium is in solution.

(4) Add balance of uranium and hold below $1000 \mathrm{C}$ until it, too, is in solution.

(5) Raise temperature of melt to $1260 \mathrm{C}$ and hold for $10 \mathrm{~min}$.

(6) Five minutes before pouring, add the stick tin and stir vigorously.

(7) Increase temperature to $1290 \mathrm{C}$; stix and skim melt.

(8) Pour into graphite mold heated to $200 \mathrm{C}$. 
During solidification it was noted that the ingots containing zirconium appeared to boil in the mold. Upon sectioning these ingots it was evident that this boiling was due to the evolution of gases during solidification. No boiling was detected in the ingots containing tin. Therefore, it was thought that perhaps the gas evolved was due to hydrogen taken into the melt with the zirconium. An analysis of the zirconium revealed that it contained 17 ppm of hydrogen. In an effort to further substantiate the fact that the hydrogen was carried into the melt by the zirconium, a master alloy of aluminum-zirconium was prepared in an inert-electrode arc furnace. This was then crushed and used to produce a melt of aluminum- $35 \mathrm{w} / 0$ uranium $-3 \mathrm{w} / 0$ zirconium. The resulting ingot exhibited much less porosity than did the ingots made with unalloyed zirconium. The hydrogen content of the zirconium thus does not prohibit its use as an alloying element in aluminum-uranium alloys since two practical methods of removing the hydrogen prior to melting are available. These methods are prealloying, which would necessitate an additional melting step, and vacuum degassing of the zirconium. Neither of these steps would substantially increase costs or interfere with the normal melting operations.

Due to the extreme porosity exhibited by the air-melted alloys containing zirconium, it was decided to renelt these ingots under helium to remove the molecular hydrogen and produce sounder castings. The cycle used for remelting was as follows:

(1) The ingot was charged into an $\mathrm{Al}_{2} \mathrm{O}_{3}$ crucible at $1000 \mathrm{~F}$.

(2) It was covered with a helium blanket and the power was turned on.

(3) When the melt reached $1290 \mathrm{C}$ it was stirred vigorously and poured. into a graphite mold.

The remelting resulted in a substantial reduction in the gas content of the melts. This reduction in gas was reflected in the quiet pour, the complete absence of boiling during ireezing, and the integrity of the cast ingots. Whereas the melts made from virgin material exhibited gas holes up to $1 / 4$ in. in diameter, the remelt ingots exhibited holes of $1 / 8$ in. diameter or less, and these were less numerous. It was estimated that the porosity was decreased 75 per cent upon remelting.

In addition to the air-melted alloys, a series of melts containing $0.5,1,1.5,2$, and 3 w/o zirconium was prepared in vacuo. These melts were prepared in a similar manner to the air-melted alloys with the exceptions that the zirconium was added to the molten aluminum approsimately 5 min before the addition of the first portion of the uranium charge and the length of the ingot was limited to less than 9 in. due to the smaller furnace capacity. This xesulted in a decrease in melting time of up to $30 \mathrm{~min}$. The ingots produced by vacuum melting were completely free of any evidence of gaseous porosity and exhibited a much finer macrostructure than did the ingots produced by air melting.

The ingots produced by air and vacuum melting were evaluated by macrographic and micrographic examination, by radiographic techniques, and by chemical analysis of representative specimens. The macrographic examinations revealed a very fine cast structure in the lower portion of the air-melted alloys and throughout the vacuum-melted material. The structure of the air-melted materials coax sened perceptibly toward the top of each ingot. In Figures 2,3 , and 4 are shown top and bottom sections from airmelted ingots. The structures exhibited by the vacuum-melted alloys are shown in Figures 5 and 6. Notice the relatively coarse structure of the top sections of the airmelted ingots and the fine structure exhibited by the vacuum-melted alloys. 




18

RM14321

FIGURE 2. SECTION OF TOP AND BOTTOM OF AN AIR-MELTED ALUMINUM-35 W/O URANIUM-ALLOY CASTING Note the fine structure exhibited by the botrom of the casting (left) and the much coarser structure at the top (right).

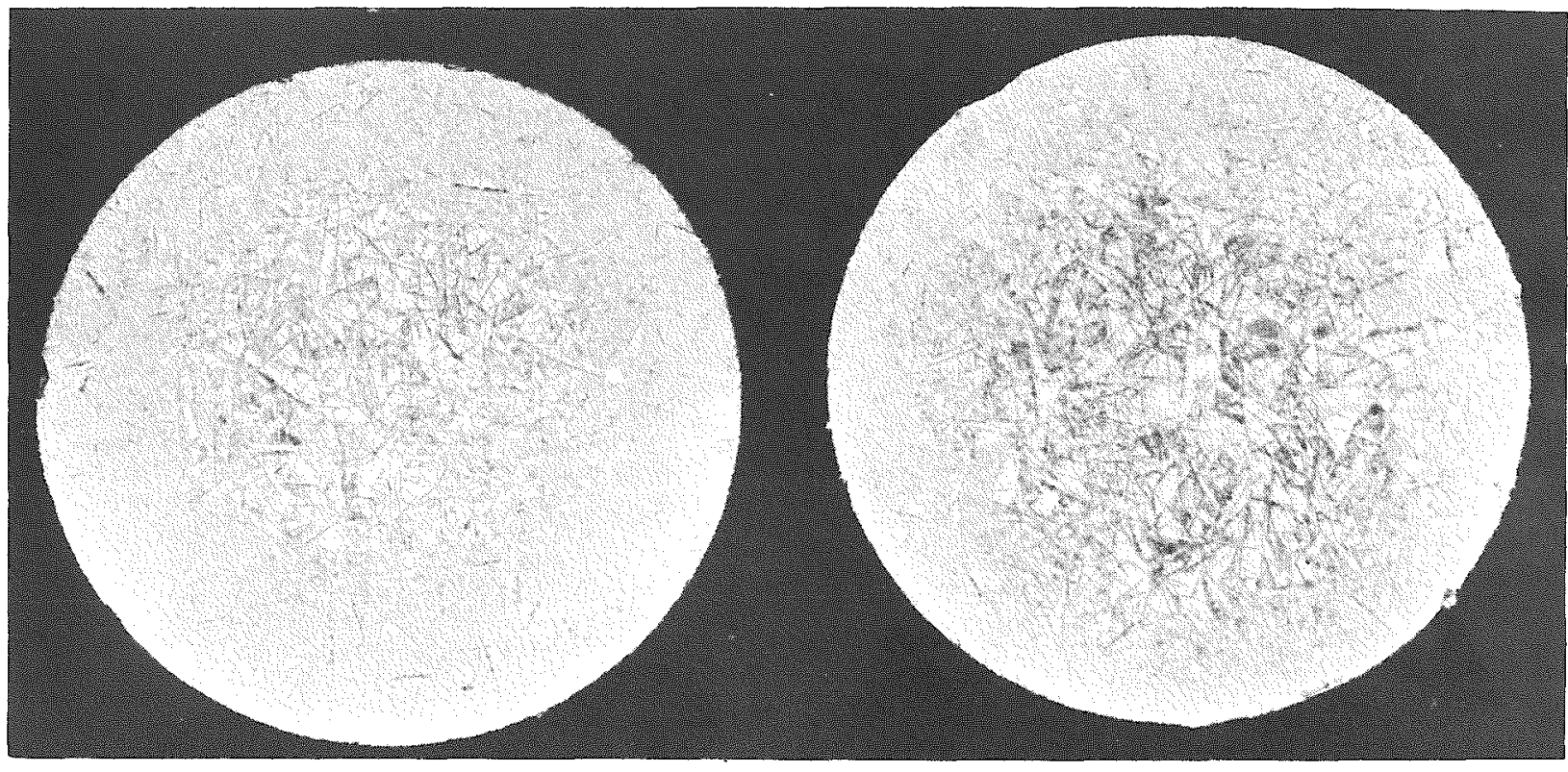

IX

RM14318

FIGURE 3. TOR AND BOTTOM SECTIONS OF AN AIR-MLLTED ALUMLNUM-35 W/0 URANIUM-2 W/O TIN-ALLOY CASTING

Note the coasser structure of the section (xight) from the top of the ingor. 


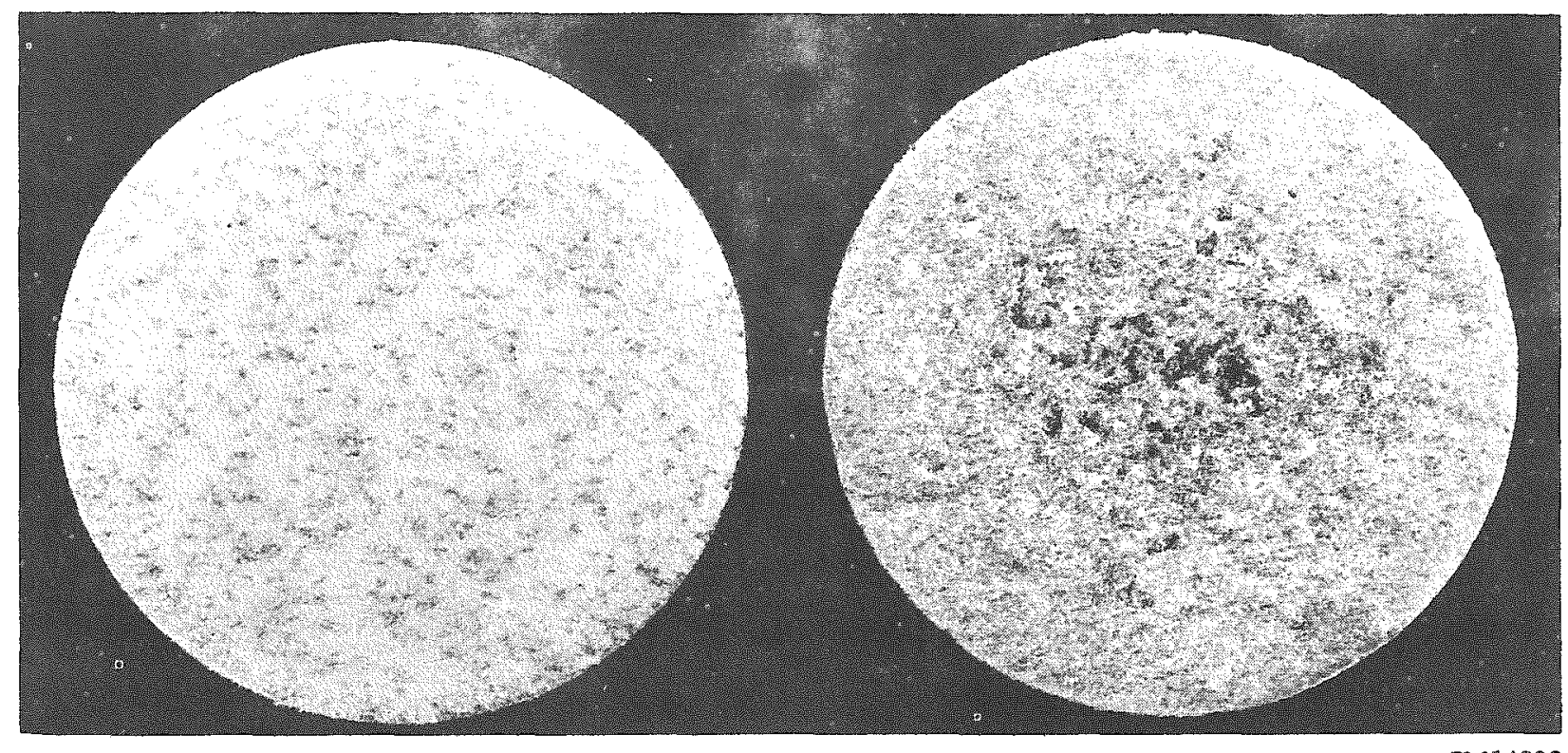

1X

FIGURE 4. TOP AND ROTTOM SECTIONS OF AN AIR-MELTED CASTING OF THE ALUMINUM-35 W/0 URANTUM-2 W/O ZIRCONIUM ALLOY AFTER REMELTING

Stuctual change from top (nght) to bottom of ingot is less evident than in the air-melted alloys in Figures 2 and 3. Both sections show some porosity.



11

RM 14368

FIGURE 5. SECTIONS FROM A VACUUM-MELTED CASTHG OF THE ALUMENU-35 $/ 0$ URANIUM-2 W/O ZIRCONIUM ALLOY

Note the fine structure in both top (right) and bottom sections and the complete absence of pososity. Note also the similar structure shown in Figuse 6. 


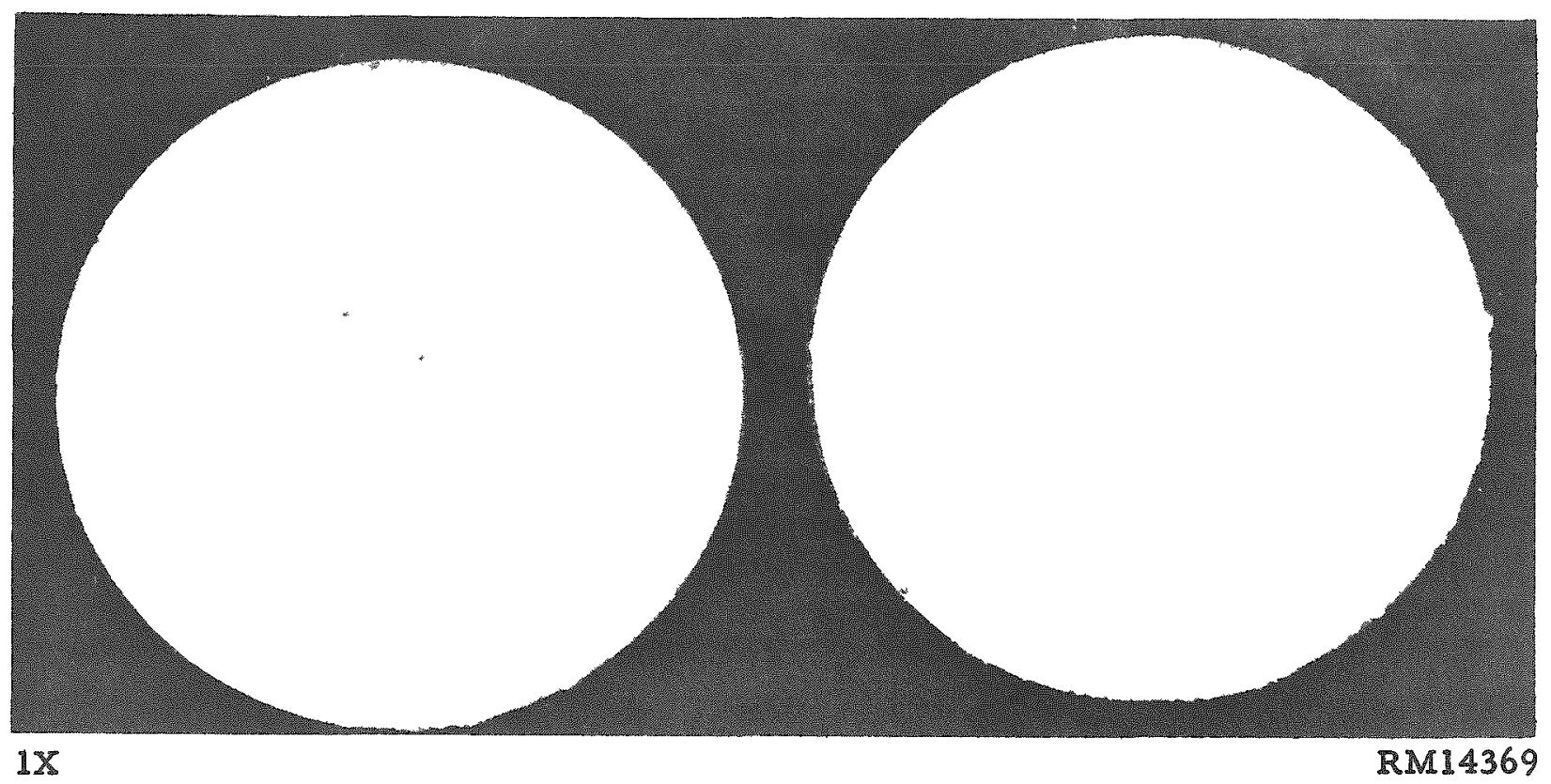

IIIGURE 6. SECTIONS FROM TOP AND BOTTOM OF A VACUUM-MELTED CASTING OF THE ALUMINUM-35 w/O URANIUM-3 w/O ZIRCONIUM ALLOX

Note the fine structure in both the top (right) and bottom sections.

The radiographic examination of the ingots was conducted on $1 / 2$-in. -thick slices from both the top and bottom of each ingot. In Figure 7 are shown typical radiographs of sections from air-melted and vacuum-melted ingots. In can be seen that the air-melted material exhibited some porosity at or near the top of the ingot. Even after remelting, the ingots containing zixconium were more porous than the once-melted ingots containing tin: however, the effects of remelting on the reduction of the entrapped gas was evident. The radiograph shown in Figure 7 of the vacuum-melted material illustrates the integrity typical of the ingots prepared by this technique.

Another effect that can be seen in the radiographs is that caused by compoundparticle size. The radiographs delineate the relatively large needle-shaped particles often found in the top section of the air-melted materials. This difference in particle size is attributed to the freezing rates imposed on the different sections of the ingot.. The absence of large particles in the vacuum-melted material is attributed to changes in the molding techniques and to the smaller volume of the charge used for the se melts.

Since radiographic examinations have proved to be a relatively accurate method of estimating composition it was not deemed necessary to obtain chemical analyses on all of the ingots. Therefore, only those ingots that appeared to exhibit the greatest varia tion in $X$-ray transmission were analyzed. The analyses revealed that the maximum uranium variation from top to bottom of a cropped ingot was less than 1.5 w/o and that in most cases the uranium content varied less than 1 w/o from top to bottom of the ingot. The binary alloy ( $35 \mathrm{w} / \mathrm{o}$ uranium) exhibited the greatest variation in uranium content from top to bottom of the ingots. The $3 \mathrm{w} / 0$ tin alloy exhibited the least. 

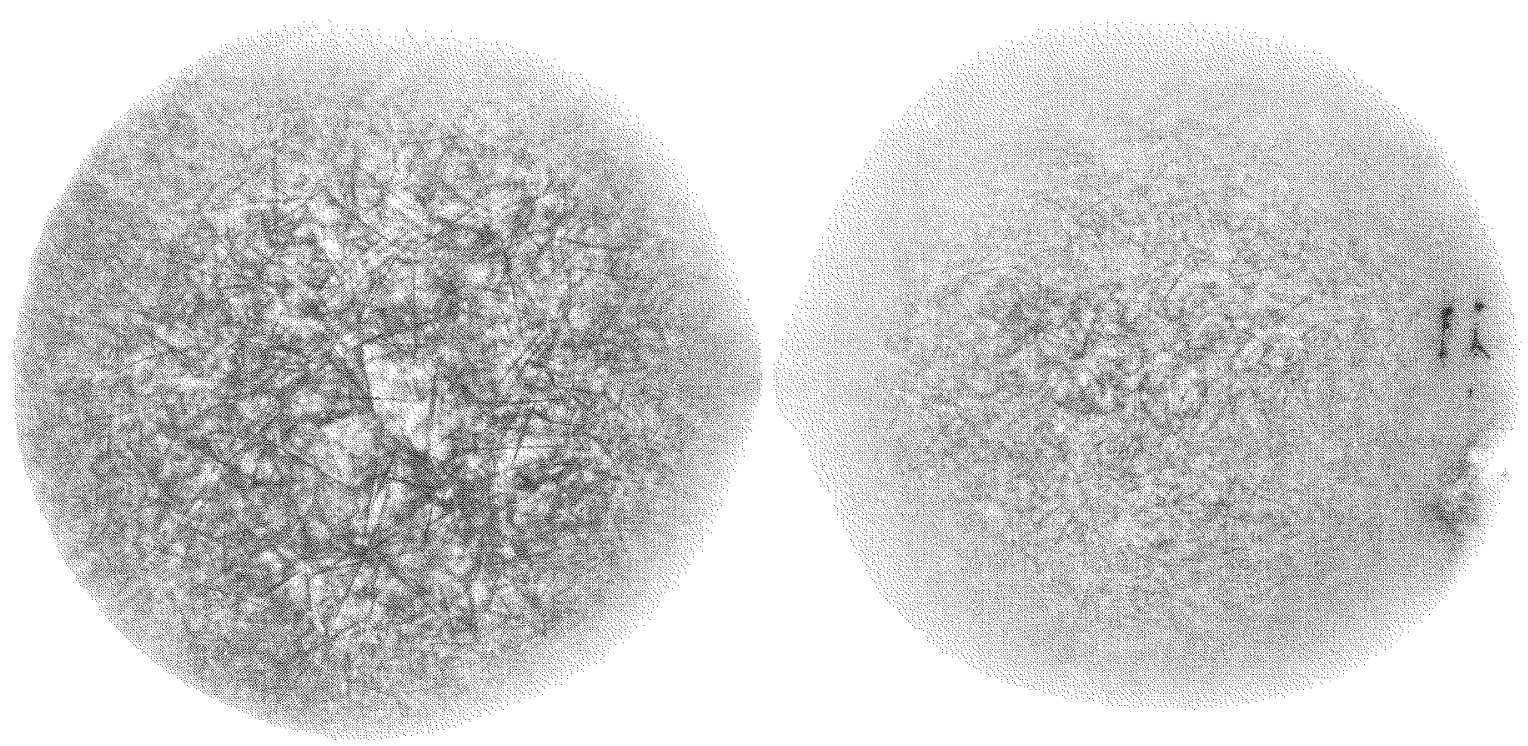

a. Air-Melted Casting of Aluminum-35 w/o Uranium-2 w/o Tin Alloy
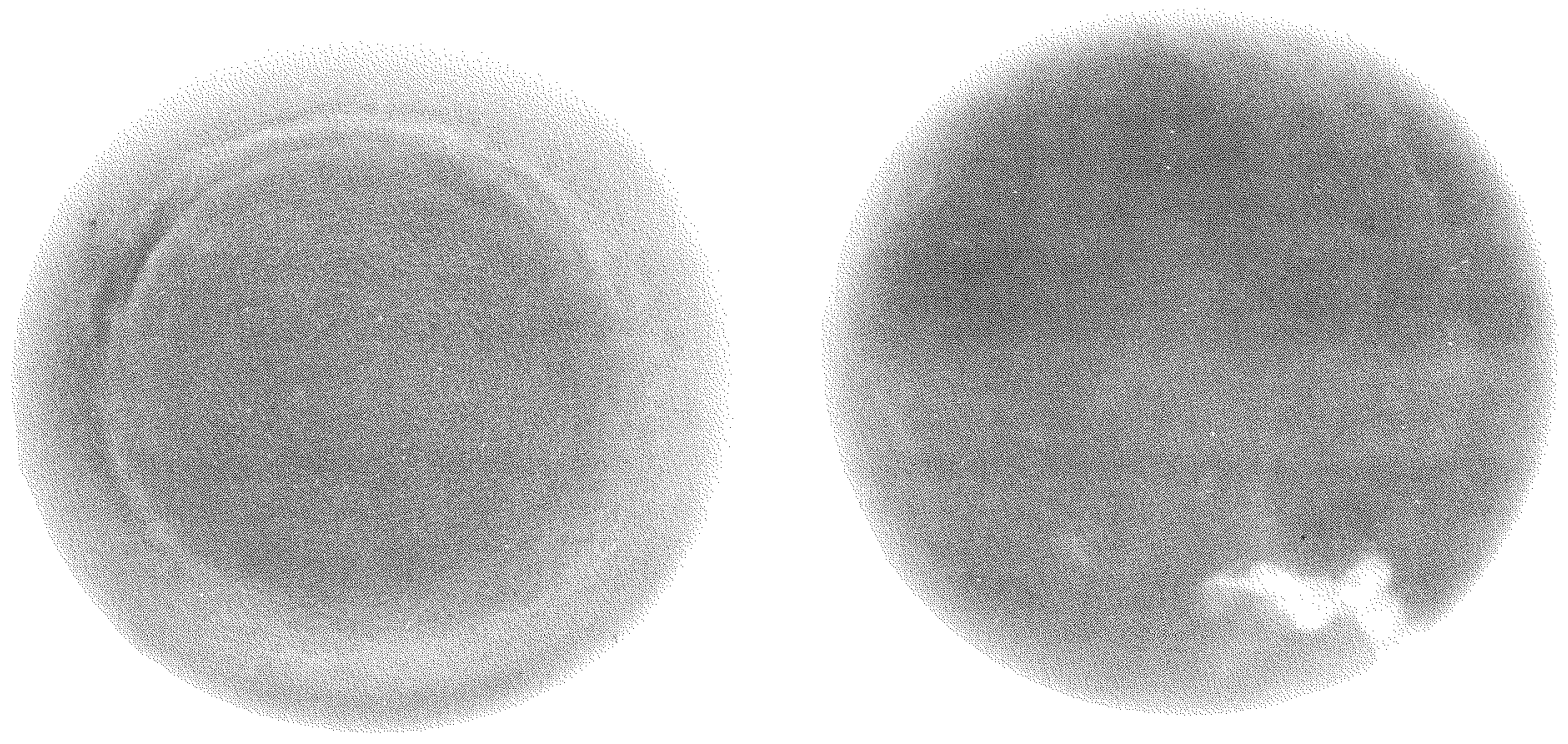

b. Vacuum-Melted Casting of Aluminum-35 W/0 Uranium-3 W/o Zirconiun Alloy

FIGURE 7. TYPICAL RADIOGRAPHS OF TOP AND BOTTOM SECTIONS FROM THE EXPERMENTAL CASTINGS

Note the change in structure form top (right) to bottom in the ais-melted alloy. Notice also the pososity and the large compound particle size in the top section of the air-melted casting. 
Fluidity Tests

Since one of the suspected advantages of the addition of tin or zirconium to the aluminum-uranium alloys was increased fluidity, an obvious test that could be conducted concurrently with the casting studies was the standard fluidity test employing a graphite mold. Duplicate fluidity-test castings were made from the same heats as were the ingots. A comparison of the length of the spiral obtained in each test was used as an indication of the fluidity of each alloy composition. It was found that, among the compositions containing $35 \mathrm{w} / 0$ uranium, the maximum fluidity occurred in a ternary alloy containing $1.5 \mathrm{w} / 0$ tin. Increased quantities of tin had little or no effect on the fluidity. It was also noted that additions of zirconium did not appreciably increase the fluidity of the aluminum- $35 \mathrm{w} / \mathrm{O}$ uranium alloy. For purposes of comparison an aluminum-25 $\mathrm{w} / 0$ uraniun alloy was tested also. This alloy exhibited a fluidity spiral approximately three times as long as did the binary aluminum - 35 w/o uranium alloy. Typical photographs of the fluidity-test specimens are shown in Figure 8.

\section{EXTRUSION STUDIES}

Six-inch-long sections of sixteen 3 -in,-diameter ingots were machined to $2-3 / 4-$ in.-diameter billets. Each billet was then inserted into a 25 aluminum tube with $1 / 8$-in, thick walls and each end of the tube was sealed with 1/4-in. -thick 25 aluminum inserts held in place by tack welding. These $6-1 / 2-i n$-long canned billets were then extruded utilizing the conditions outlined below.

$\begin{array}{ll}\text { Billet temperature } & 430 \mathrm{C} \\ \text { Container temperature } & 430 \mathrm{C} \\ \text { Die temperature } & 320 \mathrm{C} \\ \text { Ram speed } & 20 \mathrm{in.} \text { per min } \\ \text { Reduction } & 16 \text { to } 1 \\ \text { Lubricant } & 1 \text { part of Aquadag, } 16 \text { parts of lead, } \\ & \text { and } 3 \text { parts of water (by weight) } \\ \text { Die } & \text { Mild steel; entrance angle of } 90 \mathrm{deg}\end{array}$

During extrusion a graphic record was obtained of the extrusion pressures by use of a pressure recorder connected to the hydraulic system of the press. These recordings revealed that, in the case of the air-melted alloys, as the tin or zirconiun content in the alloys increased there occurred a reduction in extrusion pressure, and therefore, a Ieduction in extrusion constants. This is a manifestation of the increased quantity of ductile matrix in the alloys as a result of the retention of UAl3. However, the vacuummelted alloys required greater extrusion pressures than did similar air-melted alloys, and the vacuummelted alloys containing 2 and 3 w/o zirconium required greater extrusion pressures than did the airmmelted binary alloy. This increase in the extrusion 




Aluminum-35 $/ 0$ ปrani

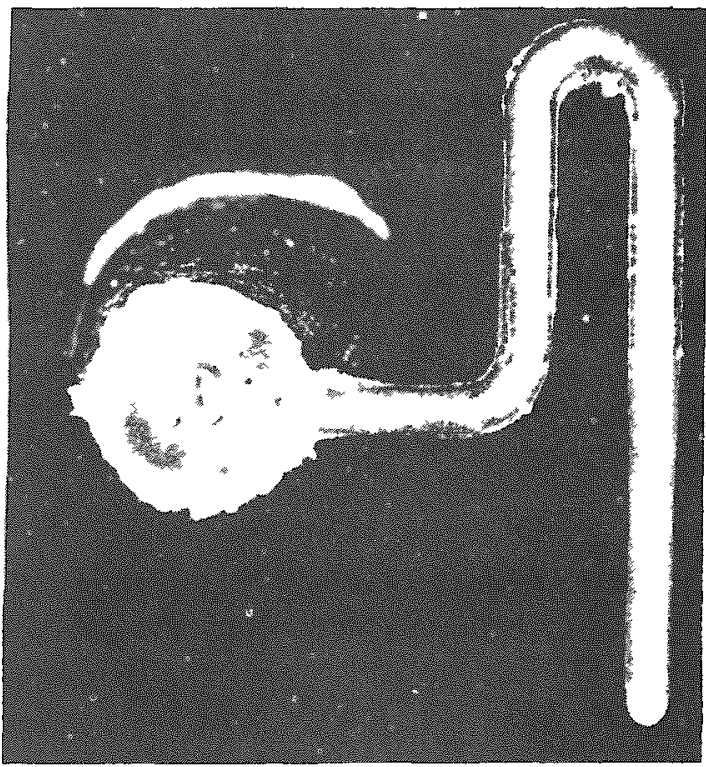

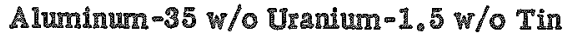

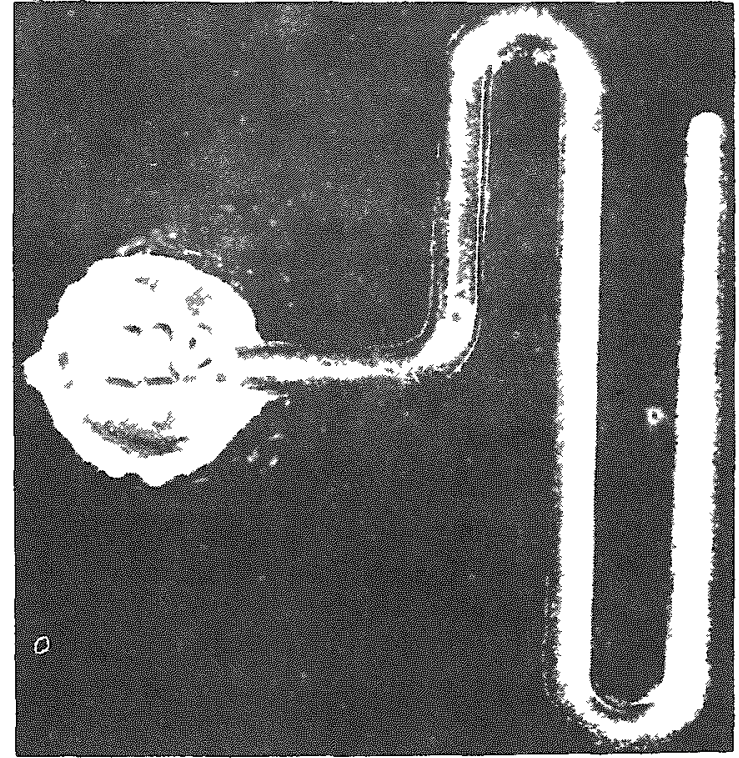

Aluminum-25 $\mathrm{w} / 0$ Uransum

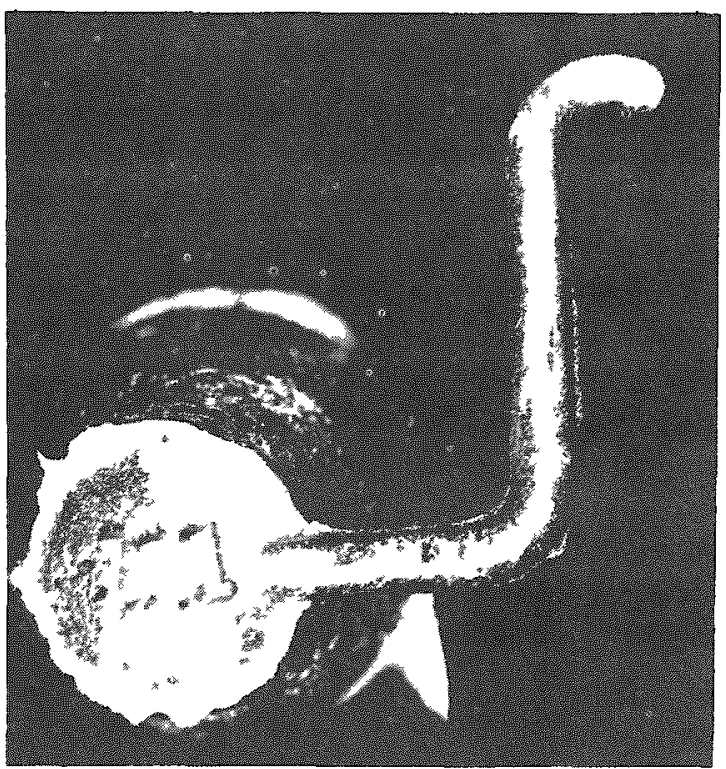

Alumunum-35 w/o Uranum-3 w/o Zirconium

FGURE 8. SPECIMENS FROM FLUDITY TESTS

The effectiveness of the tin addition in producing partial recovery of the fluidity lost through employment of a highes uranium content is evident. 
pressure required to form vacuum-melted material is attributed to the small particle size exhibited by this material.

Pressures recorded are shown in Figure 9. These pressures are listed as the pressure (a) necessary to initiate extrusion, the pressure (b) required to sustain the extrusion rate, and the final pressure (c) noted. Of course, after the material begins to flow less pressure is needed to continue the operation. A typical extrusion-pressure recording is shown in Figure 9.

The recording shows that in the initial stages of operation there is a rapid increase in pressure until the die cavity is filled, when the highest pressure is recorded. At this time there occurs a slight and steady decrease in pressure as the billet length decreases. The last pressure recorded represents the pressure necessary to extrude at the 20 in. - per-min ram speed with less than 1 in. of the billet in the container.

\section{EVALUATION OF EXTRUDED AILOYS}

\section{Metallographic Examination}

One of the most important considerations in evaluating the effectiveness of the ternary additions to the aluminum-35 w/o uranium alloy was the ability of these additions to inhibit the UAl3-to-UAl4 transformation. Two techniques were employed to identify the phases present in the as-cast and extruded alloys. These techniques were $X-r a y$ difraction and metallographic examination. The first was used only on a few select specimens to substantiate findings of metallographic examinations. Metallographic examination was employed extensively on as-cast, extruded, and heat-treated specimens. Sections from the top and bottom of each ingot were used to evaluate the as-cast material. These specimens were polished utilizing normal metallographic techniques and employing a diamond polish prior to etching. The most useful etchant for the identification of the phases present in the alloys was the standard "Keller etch" $\left(\mathrm{H}_{2} \mathrm{O}-2.5\right.$ volume per cent $\mathrm{HNO}_{3}-1.5$ volume per cent $\mathrm{HCl}-1.0$ volume per cent $\mathrm{HF}$ ) or a modification thereof. Modifications of the etch usually consisted of increasing the HF content to $\approx 2.0$ volume per cent.

The examination of the alloys containing 0.5 to $2 w / 0$ tin revealed well-defined reaction zones surrounding the larger compound particles. The extent of this reaction zone was a function of the tin content. As the tin content was increased the amount of the detectable reaction zone decreased. This can be seen by an examination of the photomicrographs shown in Figure 10. In Figure 10d is shown the as-cast structure of the alloy containing $3 \mathrm{w} / 0$ tin. Although this appears to have a fine layer surrounding the primary particles, no $\mathrm{UAl}_{4}$ was detected in this specimen by $\mathrm{X}$-ray diffraction. In Figure $10 \mathrm{e}$ is shown the structure of the binary aluminum-35 w/o uranium alloy found in the top of the ingot. The relatively large compound particle size and the extensive eutectic phase characteristic of this alloy are evident in the photomicrograph.

Photomicrographs of the as-cast air-melted alloys containing zirconium additions are shown in Figure 11. In most of these alloys it was noted that the zirconium decreased the primary particle size. The photomicrographs of the alloys containing 1 and 1. 5 w/o zirconium show rather large particle sizes. This anomaly can be explained on the basis of the sample selection and is not indicative of a trend in particle size. The 
Typical Extrusion Pressure on 26-In. Ram at

Point Shown, psi

Alloy Composition, w/o

\begin{tabular}{lrrrr} 
Composition, w/o & & \multicolumn{3}{c}{ Point Shown, psi } \\
\cline { 5 - 6 } \cline { 5 - 6 } Al-35 U & & & b & c \\
Al-35 U-2 Sn & & 1250 & 1100 & 650 \\
Al-35 U-3 Sn & 1150 & 9000 & 500 \\
& & & \\
Al-35 U-2 Zr & 1100 & 975 & 600 \\
Al-35 U-3 Zr & 1000 & 950 & 600 \\
Al-35 U-2 Zr(a) & 1250 & 1125 & 750 \\
Al-35 U-3 Zr (a) & 1300 & 1150 & 750
\end{tabular}

(a) Vacuum melted; all others air melted.



FIGURE 9. TYPICAL EXTRUSION-PRESSURE DIAGRAM OBTAINED ON ALUMINUM-35 W/O URANIUM ALLOYS WITH TERNARY ADDITIONS OF TIN OR ZIR CONIUM 


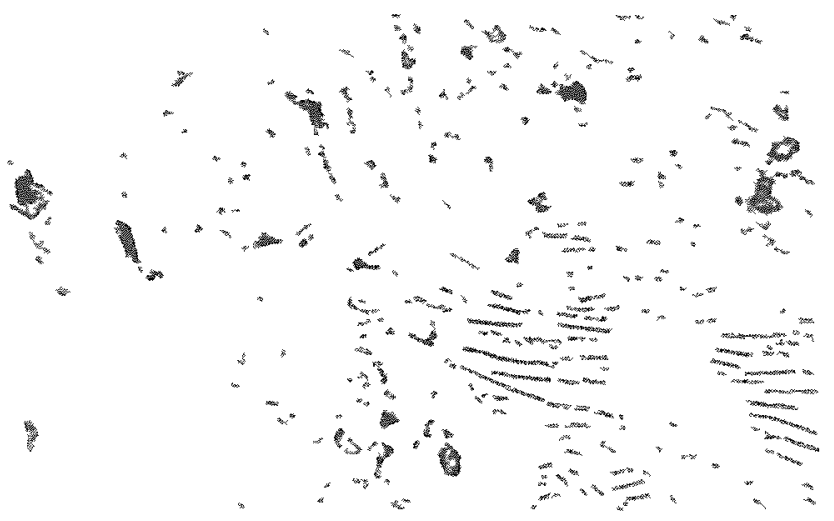

$250 x$

RM14417

a. $0.5 \mathrm{~W} / 0 \mathrm{~T}$ Th

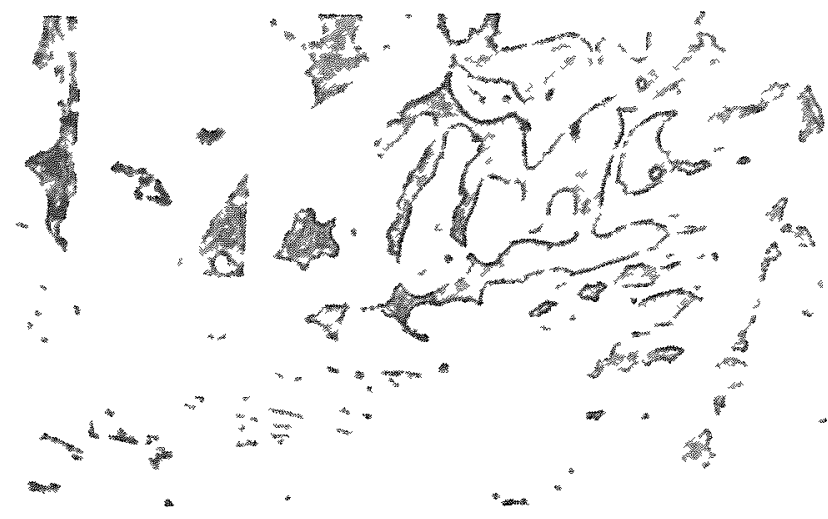

$250 \%$

RM14A22

b. $1 w / c$ Tin

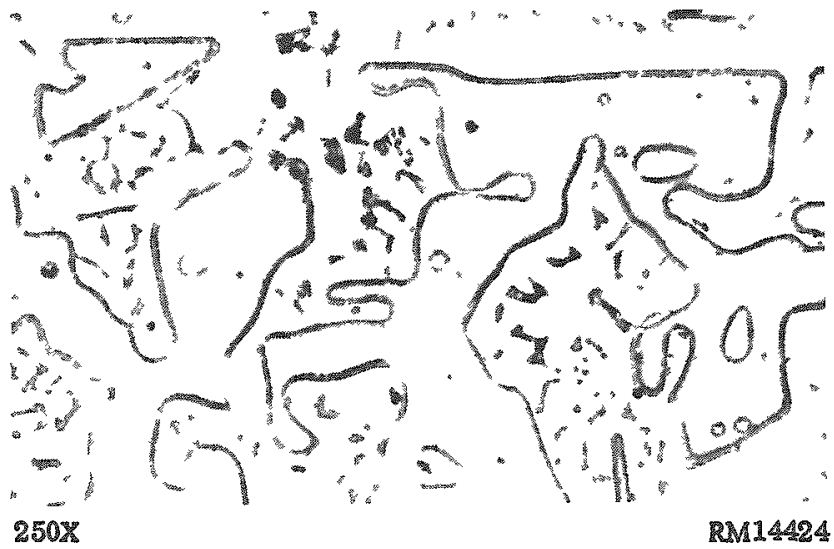

c. $2 \mathrm{~W} / 0 \mathrm{Tin}$



$250 x$



d. 3 w/o Tin

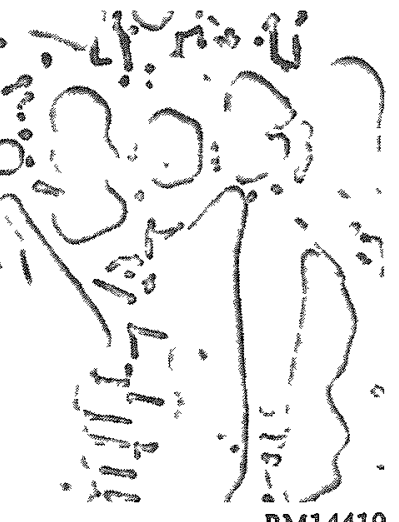

RM14A19

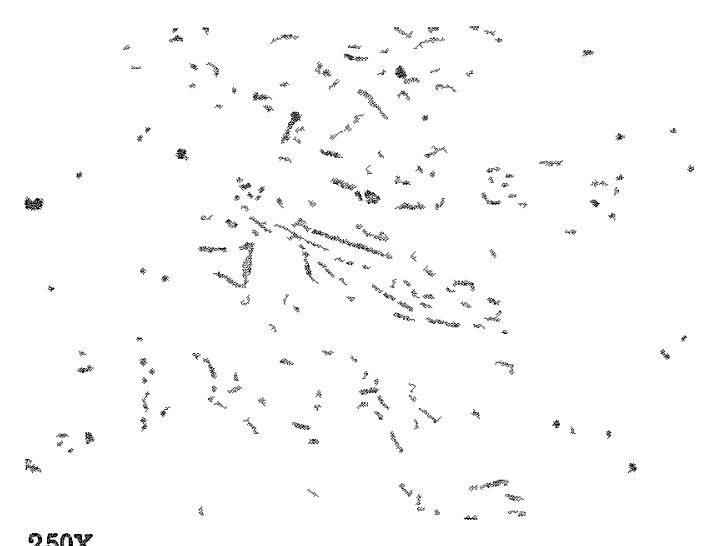

e. No Addiuion
RM14410

FIGURE 10. AS-CAST STRUCTURES OF ALUMINUM-35 W/O URANIUM ALLOYS CONTAINING ADDITIONS OF UP TO 3 W/O TIN

All ternary specimens are from the top of the ingot. Notice the reaction zones surrounding the large primary particles. The primary particles in the 2 and $3 \mathrm{~W} / \mathrm{O}$ tin alloy microstructures are composed of UAl3 outined with $\mathrm{UAI}_{4}$. In the 0.5 and $1 \mathrm{w} / 0$ tin alloys, the UA13, which in these cases is the dark-etching phase, exhibits a much more extensive reaction zone of UAl4. 


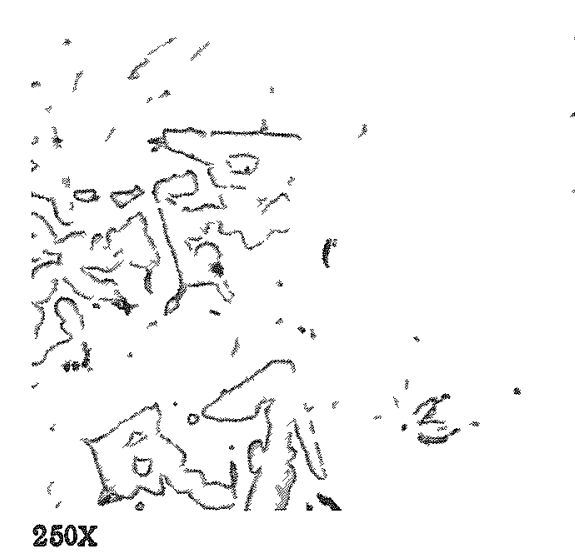

a. $0.5 \mathrm{w} / 0$ Zirconium

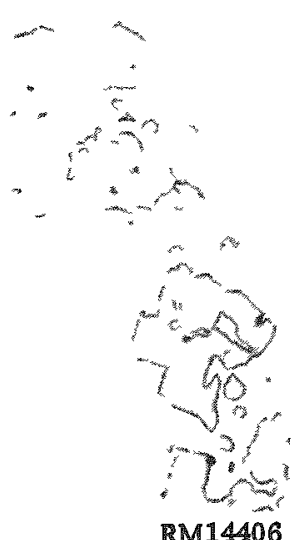

RM14406

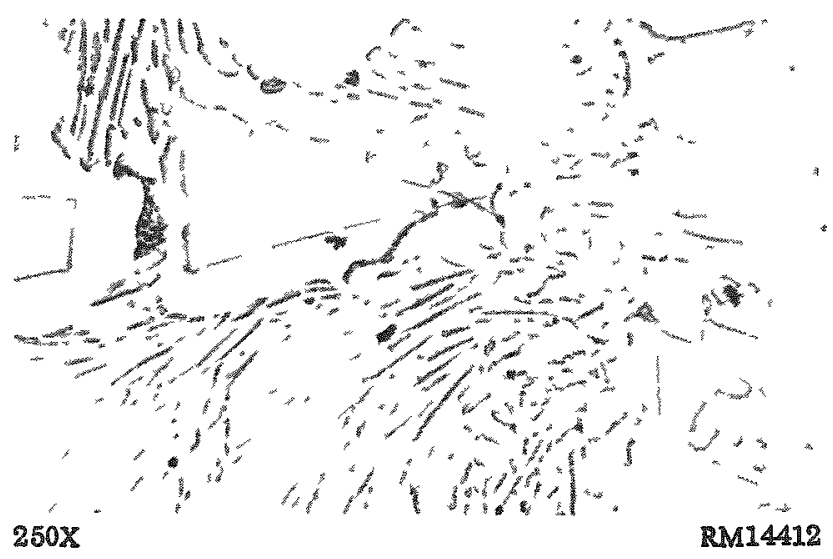

b. $1 \mathrm{w} / \mathrm{o}$ Zirconium

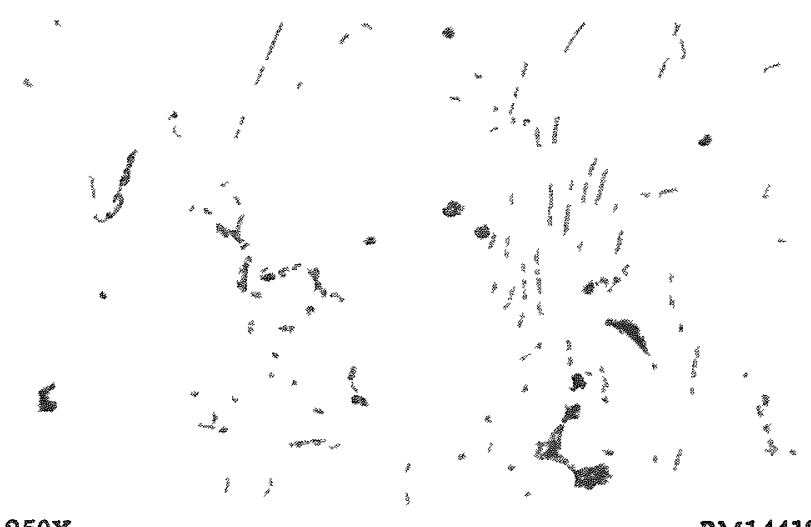

c. 1.5 w/o Zirconium

RM14413



$250 \mathrm{X}$ d. 2 w/o Zirconium

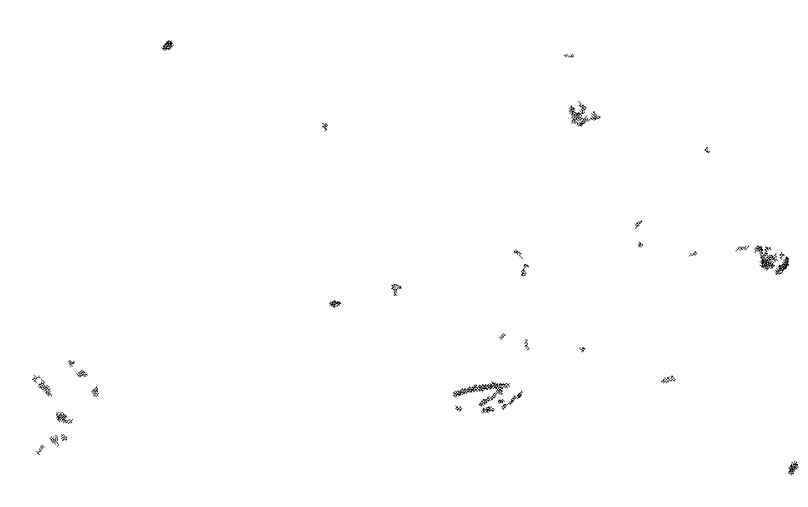

RM14414 250X

RM14415

e. 3 w/o Zirconium

FIGURE 11. AS-CAST STRUCTURES OF AIR-MELTED ALUMINUM-35 W/O URANIUM ALLOYS CONTAINING ADDITIONS OF UP TO 3 W/O ZIRCONIUM

Generally, particle size decreased with increasing zirconium content, and the large particle sizes evident in the 1 and $1.5 \mathrm{w} / \mathrm{o}$ zirconium alloys are not typical of these compositions. Notice that the continuous phase in the $3 \mathrm{w} / 0$ zirconium alloy is nearly free of lamellar compound. All specimens were taken from the top of the ingot. 
general trend wra f tnsrar a derrease in particle size with an increase in zirconium content. However, the most obvious effect of the zirconium addition is shown in Figure 1 le of the alloy containing $3 \mathrm{w} / 0$ zirconium. Notice the continuous phase which is almost Iree of lamellar compound. This effect on the matrix was not noted in the alloys containing 0.5 to $2 \mathrm{w} / 0$ zirconium. X-ray diffraction studies showed that the $3 \mathrm{w} / 0$ zirconium alloy contained little or no $\mathrm{UAl}_{4}$.

Figure 12 shows the typical structures obtained when the zirconium-containing alloys were vacuum melted. Of particular interest is the very fine structure revealed in these photomicrographs. This was expected after the results of the macrographic and radiographic examinations.

After metallographic examination of the as-cast material was completed, Brinell hardness values were obtained for each specimen. The average values are listed in Table 1. An examination of this table indicates that all of the alloys containing tin or zirconium possessed less resistance to penetration than did the binary alloy and that the alloys containing 2 or 3 w/o tin were at least ten average hardness numbers softer than the binary. Of the alloys containing zirconium, very little can be said regarding their hardness relative to each other since no trend is evident; all average values are within the range of 44.7 to 49.9 BHN.

TABLE 1. BRINELL HARDNESS OF AS-CAST ALUMINUM-35 w/O URANIUM ALLOYS CONTAINING TERNARY ADDITIONS OF TIN OR ZIRCONIUM

\begin{tabular}{lllcc}
\hline & $\begin{array}{c}\text { Nominal Ternary Addition } \\
\text { (Balance Aluminum-35 w/o } \\
\text { Uranium), w/o }\end{array}$ & \multicolumn{2}{c}{ Brinell Hardness } & (500-Kg Load) \\
\cline { 5 - 5 } Heat (a) & Top & Bottom & Average \\
\hline 113 & None & 52.3 & 55.6 & 54.0 \\
102 & 0.5 tin & 42.5 & 48.8 & 45.6 \\
103 & 1.0 tin & 45.3 & 44.6 & 45.0 \\
104 & 1.5 tin & 42.8 & 48.0 & 45.4 \\
105 & 2.0 tin & 37.6 & 44.4 & 41.0 \\
106 & 3.0 tin & 39.4 & 45.0 & 42.2 \\
119 & 0.5 zirconium & 46.5 & 42.9 & 44.7 \\
120 & 1.0 zirconium & 54.4 & 45.4 & 49.9 \\
121 & 1.5 zirconium & 44.4 & 46.5 & 45.4 \\
122 & 2.0 zirconium & 45.4 & 51.0 & 48.2 \\
123 & 3.0 zirconium & 44.7 & 47.9 & 46.3 \\
& & & & \\
\hline
\end{tabular}

(a) Heats 119 through 123 were vacuum melted; all others were air melted.

The above studies were intended to point out the approximate tin or zirconium addition that was necessary to retain UAl3. However, since the alloys were to be fabricated and subjected to elevated temperatures for extended lengths of time it was thought essential to determine the stability of the retained UAl 3 . Therefore, specimens of each composition were heat treated at $600 \mathrm{C}$ and examined after 8,24 , and $48 \mathrm{hr}$ at temperature. In all cases, the eutectic had completely spheroidized after $24 \mathrm{hr}$. The effect of heat treating the alloys was to increase the extent of the UAl 4 in the alloys. The UAl $3^{-}$ to-UAl4 reaction progressed at a higher rate in the alloys containing tin than it did in 


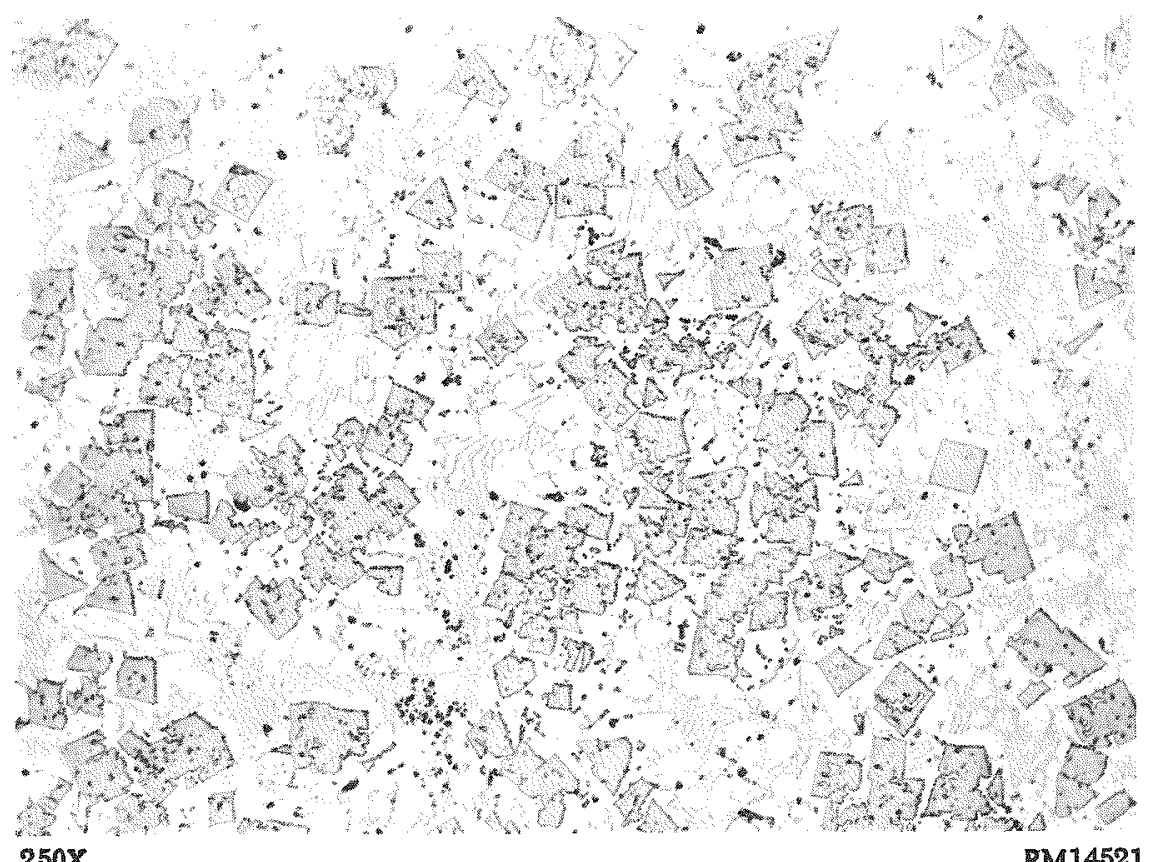

a. Aluminum-35 $w / 0$ Uranium-1.5 w/o Zirconium

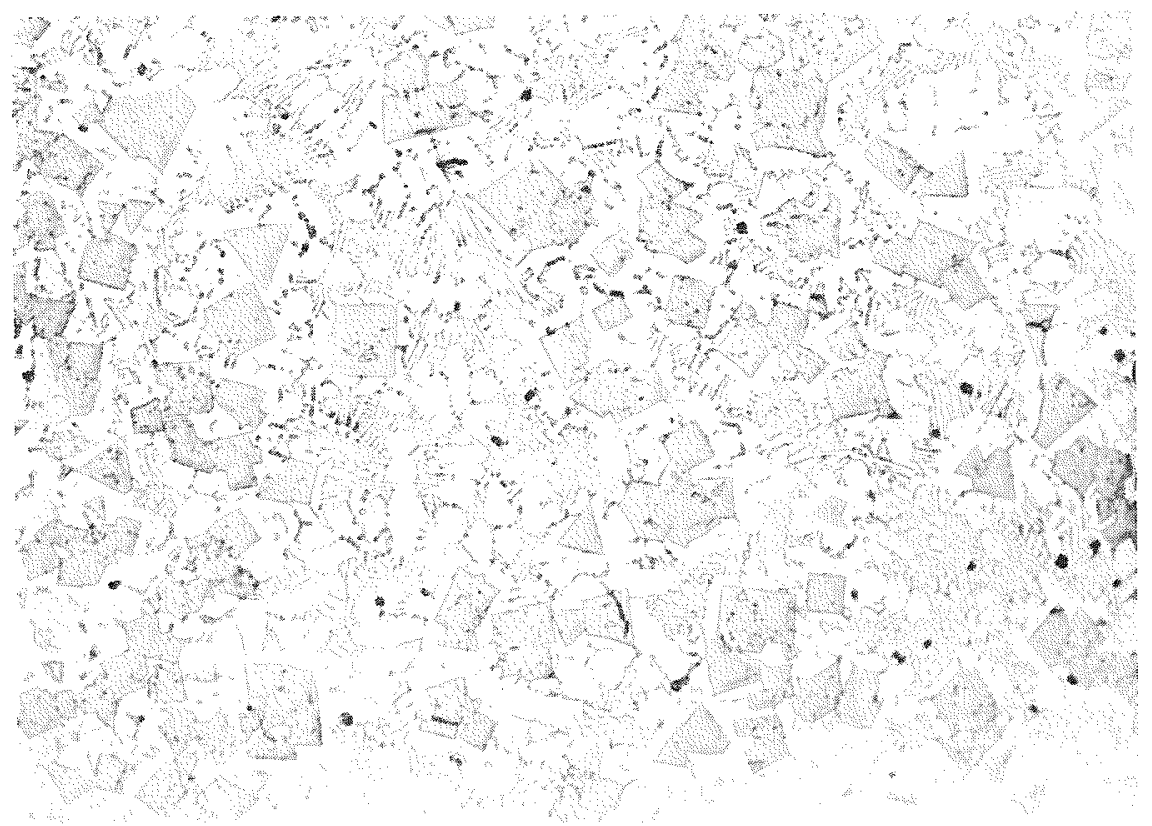

$250 \mathrm{X}$

RM14525

b. Aluminum-35 w/o Uranium-3 w/o Zirconim

FGURE 12. TYPICAL MCROSTRUCTURES OBTAIED WLEN ALUMINUM-35 W/0 URANIUM ALLOYS CONTANING ZIRCONIUM WERE PRODUCED BY VACUUM MELTING

Notice the very fine structure when compared to the air-melted alloys. 
those containing zirconium, and in all cases the reaction rate was highest in those alloys containing the smallest quantities of ternary additions. Vexy little UAlA was detected. around the periphery of the primary compounds in the alloys containing $3 \mathrm{w} / 0$ tin or zirconium after $48 \mathrm{hr}$ at temperature. The stability of the metastable phase present in the cast alloys was a function of the tin or zirconium content of the alloy and zirconium additions resulted in more stable compounds than did tin additions.

The photomicrographs shown in Figures 13 and 14 illustrate the above phenomena. The binary alloy exhibits no reaction zone as expected, since it was essentially completely UAl4 upon casting; the aluminum-35 w/o uranium-1. $5 \mathrm{w} / 0$ tin alloy exhibits a reaction which has gone almost to completion. The only areas that have not transformed to $\mathrm{UAl}_{4}$ are those within large massive compound particles. The aluminum-35 w/o uranium-3 w/o tin alloy shows a reaction zone surrounding the massive compounds, and even the spheroidized eutectic structure has not completely transformed. The aluminum$35 \mathrm{w} / 0$ uranium $1.5 \mathrm{w} / 0$ zirconium alloy shown in Figure $14 \mathrm{a}$ exhibits a reaction zone which has completely engulfed the smaller compounds and has progressed some distance into the massive compound particles when compared with the penetration shown in Figure $14 \mathrm{~b}$ of the alloy containing 3 w/o zirconium.

From the metallographic examination after the heat treatments it was obvious that less than $2 \mathrm{w} / 0$ tin or zirconium would prove of little benefit to the aluminum-35 w/o uranium alloy. The hardness of the tin alloys decreased with increasing tin content, and neither the tin nor zirconium in quantities of 2 w/o or less would inhibit the UAl $3_{-}^{-t o-}$ $\mathrm{UAl}_{4}$ transformation sufficiently to permit the fabrication of a material containing the maximum quantity of free aluminum. As a result of these studies and subsequent hothardness determinations, those alloys containing less than 2 w/o ternary addition were omitted from further testing except for corrosion tests which were already in progress.

\section{Hot Hardness}

One method used to obtain information relative to the effectiveness of the ternary additions in inhibiting the $\mathrm{UAl}_{3}$-to-UAl 4 transformation and in increasing the fabricability of the alloys was the determination of the hardness of the as-cast alloys up to $600 \mathrm{C}$. Standard hot-hardness procedures utilizing a diamond-pyramid indicator were employed. At least four indentations were made at each temperature for each alloy. The values obtained for the alloys containing 2 and 3 w/o tin or zirconium are plotted in Figure $15 \mathrm{as}$ a band. The values obtained on the binary alloy are shown as a line. The values were plotted as a band to present a more valid representation of the data than would be shown by a number of lines which were averages of values obtained over the range represented by the band. The data suggest that all of the additions of 2 w/o or more of tin or zirconium had approximately the same effect on the hardness of the alloys: this is correct. For instance, the diamond-pyramid hardness of the $2 \mathrm{w} / 0$ zirconium alloy was 21.0 at $300 \mathrm{C}$. This compares with a hardness of 21.7 for the 2 w/o tin alloy at the same temperature. The binary alloy exhibited a hardness of approximately 36 DPHIN at this temperature. Also shown by the data is the fact that all of the ternary addibions lower the hardness of the binary alloy to some extent. Therefore, there shin ild be some improvement noted in the fabricability of the se alloys due to the addicions.

The decreased hardness is attributed to the retention of $U \mathrm{Al}_{3}$ in the alloys and the corresponding increase in ductile matrix. 


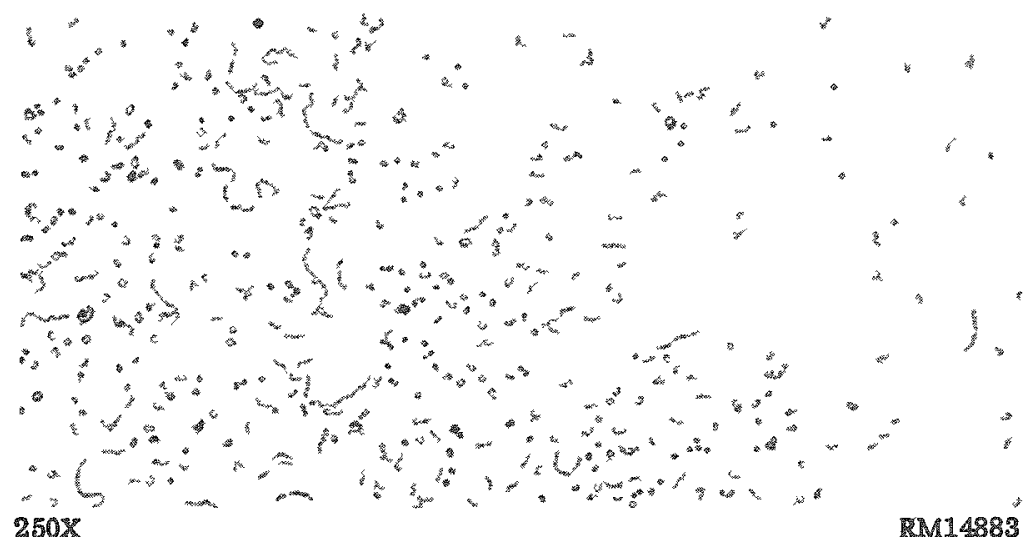

a. Aluminum-35 $w / 0$ Uranum



$250 \%$

b. Alumznum-35 w/o Uranum-1.5 w/o Tan

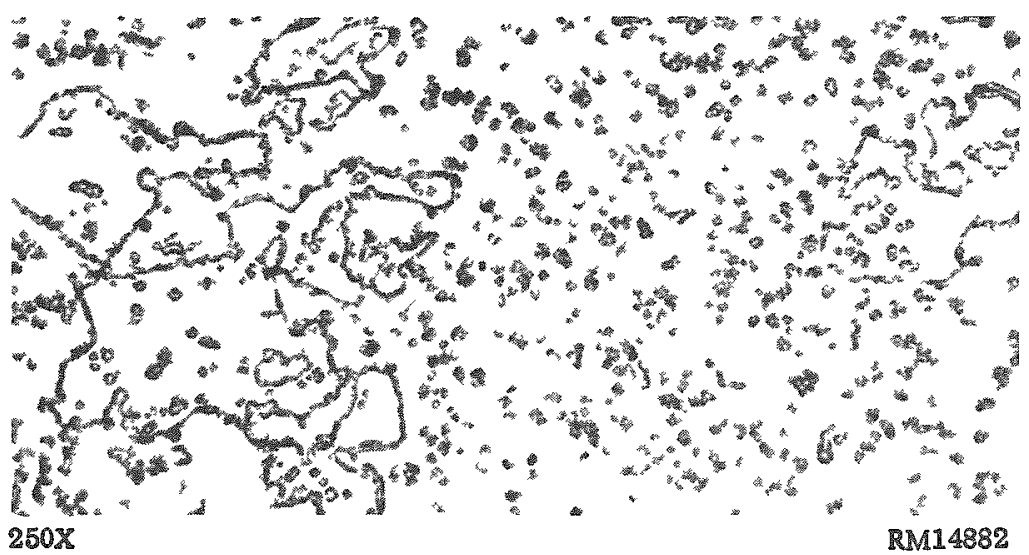

c. Alumunum-35 $\mathrm{w} / 0$ Uranum $-3 \mathrm{w} / 0$ Tin

FIGURE 13. FHFCT OF TIN ADDITONS WN STABILIZING THE UAI3 COMPOUND IN THE ALUMMNUM-35 W/O URANIUM ALLOY

The specimens were heat reated $48 \mathrm{hr}$ at $600 \mathrm{C}$. No reacuon zone is avdent in the binary alloy because the compound was UAl 4 pror to heat treatment. The alloy contaning 3 w/o tu shows only munor reaction zones surounding the partucles after the 48 -hu heat treament. 


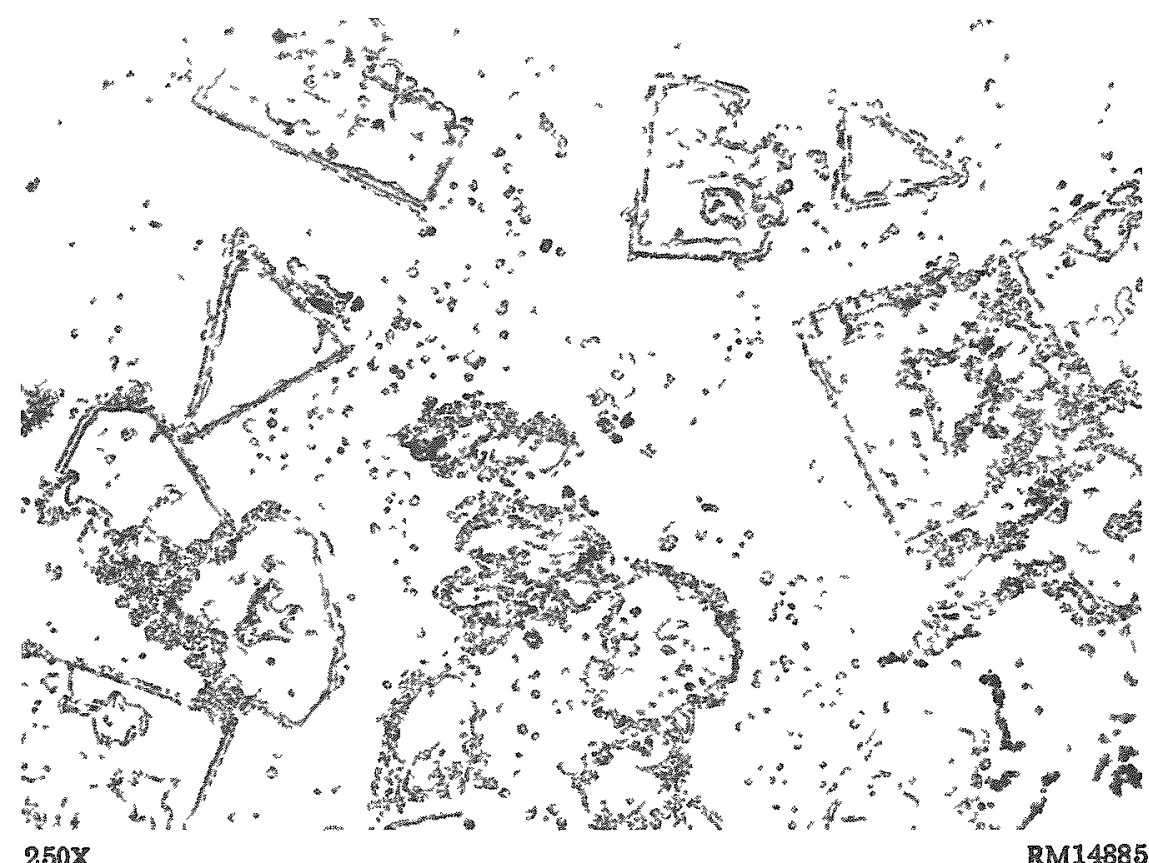

2. Aluminum-35 w/0 Uranium-1.5 w/o Zirconium

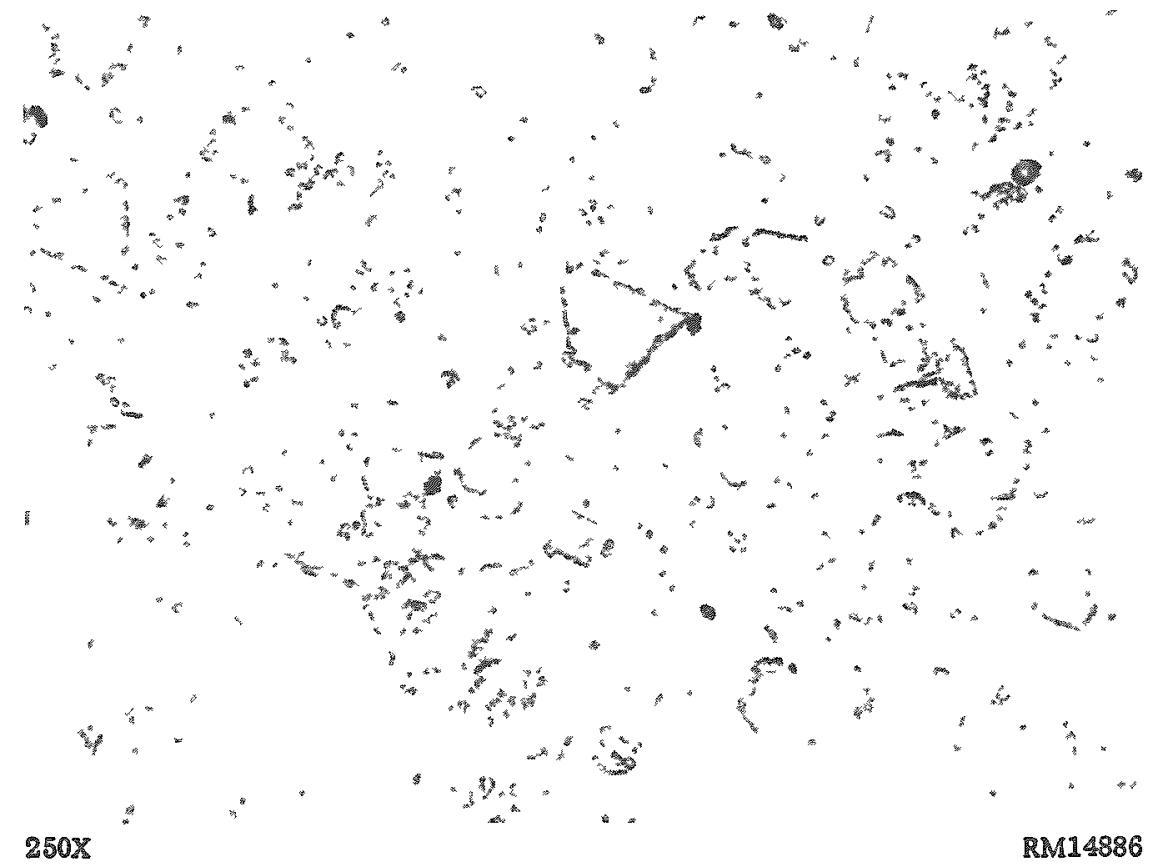

b. Aluminum - 35 w/o Uraniun -3 w/o Zirconiun

FIGURE 14. FFECT OF ZLCONIUM ADDITIONS IN STABLIZING THE UAL3 COMPOUND IN THI ALUMMNUM-35 W/O URANIUM ALLOY

The specimens were heat treated 48 hr at $600 \mathrm{C}$. For the same addition level. zirconium was more effective than in in stabilizing the UAl3. These microm stuctures should be compared winh those shown in Figure 13. 


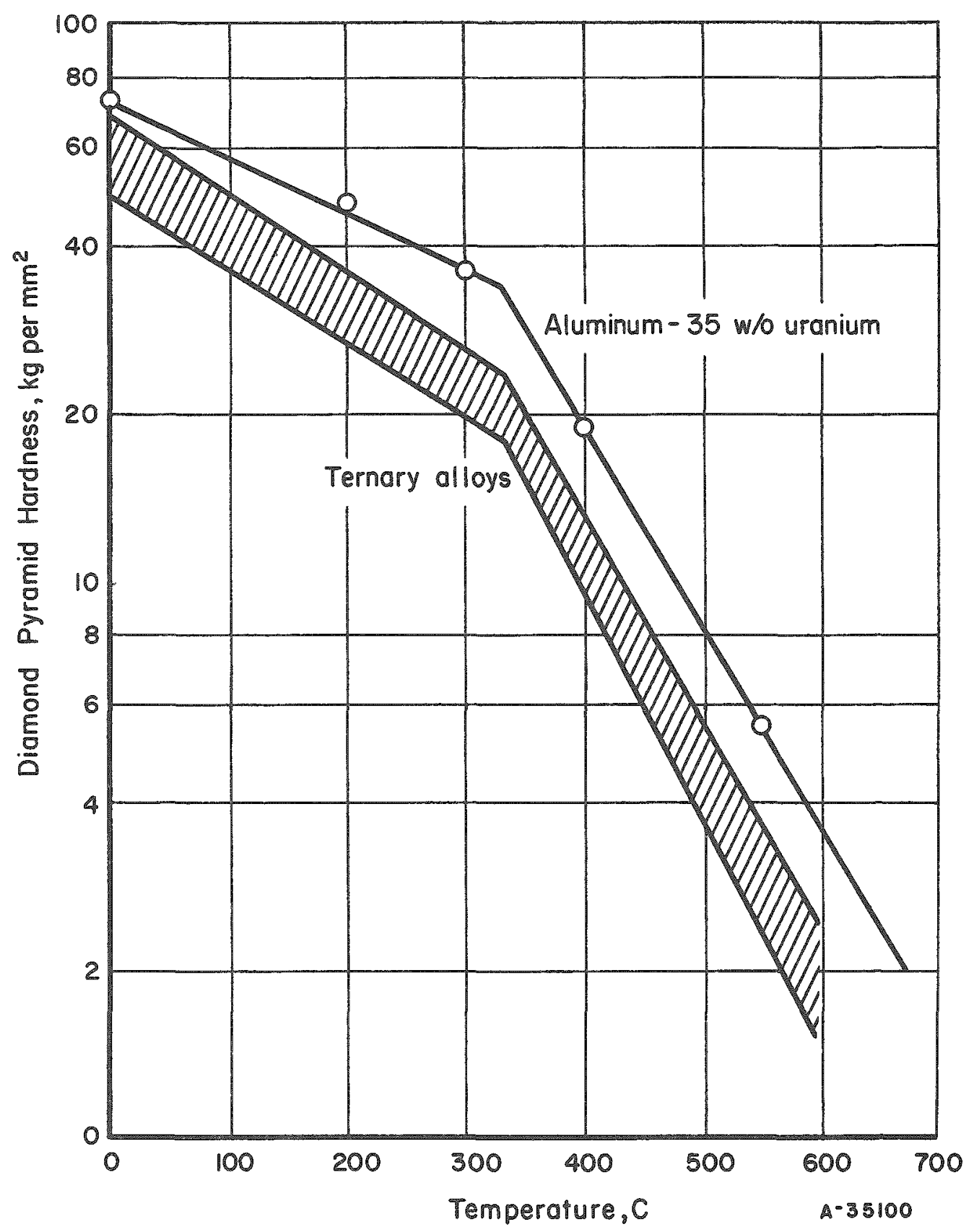

FIGURE 15. HOT-HARDNESS OF ALUMINUM-35 W/O URANIUM ALLOYS CONTAINING TIN AND ZIRCONIUM 
Tensile Tests

One of the most informative tests used to evaluate the engineering properties of material is the tensile test. The values for elongation and reduction in area of the materials obtained in this test are good indicators of the relative fabricability of similar alloys when the testing is conducted at temperatures approaching the fabrication temperatures. Further, the results of tests conducted at temperatures that may be encountered in operation are necessary for intelligent reactor design since they are indicative of the stresses that the material may resist without deformation and the subsequent disruption of the coolant flow.

For this study tensile tests were conducted at 100,250, and $400 \mathrm{C}$ on a minimum of two fabricated specimens of each composition containing $2 \mathrm{w} / 0$ or more of the ternary addition at each temperature. At $100 \mathrm{C}$ there was no discernible difference in the tensile strength of the various alloys. However, as shown in Table 2, at $250 \mathrm{C}$ there appears to be a significant difference between the ultimate tensile strength of the airmelted binary alloy and the air-melted alloys containing tin or zirconium. This difference is also apparent at $400 \mathrm{C}$. The vacuum-melted alloys containing zirconium exhibited greater ultimate strength than did the air-melted alloys of similar composition. This difference in tensile properties is attributed to the superior soundness of the vacuum-cast material.

While the elongation and reduction-in-area values are somewhat scattered they nevertheles show the definite ingrovement in plastic flow that is obtained by the addition of tin or zirconium. In all cases the alloys containing ternary additions exhibited greater elongations than did the binary alloy, and in most cases the reductions in area are greater.

\section{Corrosion Tests}

One of the most important criteria for the acceptance of an alloy for possible use as a reactor fuel is its resistance to the medium in which it is to operate. Therefore, the evaluation of the aluminum-35w/o alloys containing tin or zirconium included the determination of the corrosion resistance of these alloys in water. Tests were conducted in $150 \mathrm{C}$ demineralized water using specimens from the as cast ingots and from the extruded rods. Weight-gain determinations were made at the end of 5, 10, 20, and 30 days. For purposes of comparison, specimens of $2 S$ aluminum were tested in the same autoclave as the alloys. The weight gains exhibited by the alloys are given in Tables 3 and 4 .

An examination of these weight gains reveals that all of the alloys were superior to the 25 aluminum in corrosion resistance after 20 days of exposure. The weight gain for the $2 \mathrm{~S}$ aluminum is given at $0.88 \mathrm{mg}$ per $\mathrm{cm}^{2}$ for this time interval, and it was noted that the material was flaking and there were numerous heavy dark particles on the surface. None of the other specimens exhibited heavy dark particles of this type nor was any perceptible flaking noted. It is obvious from the results of the se tests that the additions of tin or zirconium did not impair the corrosion resistance of the alloys. In fact, it appears that tin and zirconium are beneficial in improving the corrosion resistance of the alloy under these test conditions. 
TARLE 2. TENSILE PROPERTIES OF ALUMINUM-35 W/O URANIUM ALLOYS CONTAINING TERNARY ADDITIONS OF TIN OR ZIRCONIUM

\begin{tabular}{|c|c|c|c|c|c|c|c|c|c|c|c|c|c|}
\hline \multirow{3}{*}{$\begin{array}{c}\text { Nominal } \\
\text { Ternary Addition } \\
\text { (Balance Aluminum-35 w/o } \\
\text { Uranium), w/o }\end{array}$} & \multirow{3}{*}{$\begin{array}{l}\text { Melting } \\
\text { Procedure }\end{array}$} & \multicolumn{12}{|c|}{ Tensile Properties at Temperatures shown } \\
\hline & & \multicolumn{3}{|c|}{ Yield Strength, psi } & \multicolumn{3}{|c|}{ Ultimate Strength, psi } & \multicolumn{3}{|c|}{ Elongation, per cent } & \multicolumn{3}{|c|}{$\begin{array}{c}\text { Reduction in Area, } \\
\text { per cent }\end{array}$} \\
\hline & & $100 \mathrm{C}$ & $250 \mathrm{C}$ & $400 \mathrm{C}$ & $100 \mathrm{C}$ & $250 \mathrm{C}$ & $400 \mathrm{C}$ & $100 \mathrm{C}$ & $250 \mathrm{C}$ & $400 \mathrm{C}$ & $100 \mathrm{C}$ & $250 \mathrm{C}$ & $400 \mathrm{C}$ \\
\hline None & Air melted & 15,500 & 10,300 & 3,660 & 18,600 & 12,700 & 5,100 & 4.5 & 9.0 & 10.6 & 3.3 & 4.4 & 18.3 \\
\hline 2 tin & Air melted & 14,900 & 7.680 & 3,410 & 17,800 & 10,800 & 4,170 & 7.6 & 12.2 & 13.7 & 4.07 & 13.4 & 16.8 \\
\hline 3 tin & Air melted & 15,200 & 7.080 & 3,460 & 18,400 & 10,400 & 4,390 & 9.6 & 12.7 & 12.2 & 7.0 & 13.3 & 23.8 \\
\hline 2 zirconium & Air meited & 15,100 & 8,720 & 3,440 & 18,400 & 12,000 & 4,560 & 8.0 & 14.0 & 12.6 & 3.2 & 13.7 & 16.2 \\
\hline 3 zirconium & Air melted & 14,600 & 7.650 & 2,700 & 17,100 & 10,400 & 3,870 & 10.7 & 15.4 & 18.0 & 6.7 & 20.2 & 35.7 \\
\hline 2 zirconium & Vacuum melted & 14,800 & 8,150 & 3,580 & 18,800 & 12,000 & 4,800 & 10.6 & 14.2 & 14.8 & 11.0 & 23.8 & 34.2 \\
\hline 3 zirconium & Vacuum melted & 14,500 & 7.700 & 3,880 & 18,800 & 11,400 & 5,000 & 8.2 & 12.2 & 12.4 & 4.0 & 18.0 & 18.3 \\
\hline
\end{tabular}


TABLE 3. CORROSION RESISTANCE OF AS-CAST ALUMINUM-35 W/O URANIUM ALLOYS CONTAINING TERNARY ADDITIONS OF TIN OR ZIRCONIUM

\begin{tabular}{|c|c|c|c|c|c|}
\hline \multirow[b]{2}{*}{ Heat(a) } & \multirow{2}{*}{$\begin{array}{c}\text { Nominal Temary Addition } \\
\text { (Balance Aluminum-35 w/o } \\
\text { Uraniun), } \mathrm{W} / \mathrm{o}\end{array}$} & \multicolumn{4}{|c|}{ Weight Gain in Time Shown, mg per $\mathrm{cm}^{2}$} \\
\hline & & 5 Days & 10 Days & 20 Days & 30 Days \\
\hline 102 & $0.5 \operatorname{tin}$ & 0.72 & 0.80 & 0.90 & 1.15 \\
\hline 103 & 1.0 tin & 0.48 & 0.60 & 0.72 & 0.98 \\
\hline 104 & $1.5 \operatorname{tin}$ & 0.50 & 0.55 & 0.67 & 0.88 \\
\hline 105 & $2.0 \operatorname{tin}$ & 0.39 & 0.53 & 0.61 & 0.79 \\
\hline 106 & 3.0 tin & 0.39 & 0.51 & 0.63 & 0.82 \\
\hline 113 & None & 0.31 & 0.50 & 0.46 & 0.61 \\
\hline 114 & 0.5 zirconium & 2.62 & 2.00 & 2.69 & 3.52 \\
\hline 115 & 1.0 zirconium & 2.06 & 1.77 & 2.19 & 2.88 \\
\hline 116 & 1.5 zirconium & 0.95 & 1.06 & 1.23 & 1.80 \\
\hline 117 & 2.0 zirconium & 0.70 & 0.87 & 1.04 & 2.00 \\
\hline 118 & 3.0 zirconium & 0.44 & 0.53 & 0.60 & 0.79 \\
\hline 119 & 0.5 zirconium & 0.23 & 0.30 & 0.31 & 0.43 \\
\hline 120 & 1. 0 zirconium & 0.20 & 0.30 & 0.32 & 0.47 \\
\hline 121 & 1.5 zirconium & 0.20 & 0.29 & 0.30 & 0.45 \\
\hline 122 & 2.0 zirconium & 0.23 & 0.31 & 0.32 & 0.43 \\
\hline 123 & 3.0 zirconium & 0.28 & 0.36 & 0.38 & 0.48 \\
\hline
\end{tabular}

(a) Heats 119 through 123 were vacuum melted; all others were air melted. 
TABLE 4. CORROSION RESISTANCE OF EXTRUDED ALUMINUM-35 W/O URANIUM ALLOYS CONTAINING TERNARY ADDITIONS OF TIN OR ZIRCONIUM

\begin{tabular}{|c|c|c|c|c|c|}
\hline \multirow[b]{2}{*}{ Heat(a) } & \multirow{2}{*}{$\begin{array}{c}\text { Nominal Temary Addition } \\
\text { (Balance Aluminum }-35 \text { w/o } \\
\text { Uranium), w/o }\end{array}$} & \multicolumn{4}{|c|}{ Weight Gain in Time Shown, $\mathrm{mg}$ per $\mathrm{cm}^{2}$} \\
\hline & & 5 Days & 10 Days & 20 Days & 30 Days \\
\hline & 25 aluminum & 0.43 & 0.57 & 0.88 & 2.96 \\
\hline 102 & $0.5 \mathrm{tin}$ & 0.26 & 0.36 & 0.45 & 0.60 \\
\hline 104 & 1.5 tin & 0.25 & 0.34 & 0.38 & 0.46 \\
\hline 105 & $2.0 \mathrm{in}$ & 0.26 & 0.43 & 0.51 & 0.67 \\
\hline 106 & $3.0 \mathrm{tin}$ & 0.30 & 0.37 & 0.44 & 0.57 \\
\hline 113 & None & 2.84 & 3.33 & 3.68 & 4.21 \\
\hline 114 & 0.5 zirconium & 0.27 & 0.40 & 0.47 & 0.55 \\
\hline 115 & 1.0 zirconium & 0.19 & 0.27 & 0.31 & 0.44 \\
\hline 116 & 1.5 zirconium & 0.23 & 0.30 & 0.35 & 0.51 \\
\hline 117 & 2.0 zirconium & 0.33 & 0.39 & 0.45 & 0.58 \\
\hline 118 & 3.0 zirconium & 0.23 & 0.32 & 0.37 & 0.53 \\
\hline 119 & 0.5 zirconium & 0.19 & 0.25 & 0.30 & 0.42 \\
\hline 120 & 1.0 zirconium & 0.25 & 0.32 & 0.38 & 0.49 \\
\hline 121 & 1.5 zirconium & 0.24 & 0.31 & 0.38 & 0.45 \\
\hline 122 & 2.0 zirconium & 0.24 & 0.31 & 0.36 & 0.49 \\
\hline 123 & 3.0 zirconium & 0.26 & 0.36 & 0.45 & 0.59 \\
\hline
\end{tabular}

(a) Heats 119 through 123 were vacuum melted; all others were air melted. No suitable extruded specimen was obtained from Heat 103 for corrosion testing. 
Creep-rupture tests were conducted in conventional lever-arm creep-test units. Testing procedures were in accordance with those specified in the ASTM recommended practice for conducting time-for-rupture tensile tests of materials. (4) The atmosphere for all tests was static air. Since previous tests had shown that additions of less than 2 w/o tin or zirconium had little or no beneficial effect on the properties of the alloy, only those alloys containing 2 and $3 \mathrm{w} / 0$ additions were tested and compared with the binary aluminum-35 w/o uranium alloy. The program was first set up to determine the 100-hr rupture strength of each alloy at $200 \mathrm{C}$ (392 F). Subsequently, additional specimens were used to extend the data for five of the alloys to $1000 \mathrm{hr}$.

Curves of stress versus rupture and rupture time were drawn on logarithmic coordinates. From these curves, the stresses for rupture in $100 \mathrm{hr}$ and $1000 \mathrm{hr}$ were determined and are listed in Table 5. From these values it can be seen that both tin and zirconium decrease the rupture strength of the alloy, and that, of the two, zirconium is less detrimental than is tin. It can also be seen that the vacuum-melted alloys exhibited some improvement over the corresponding air-melted alloys. The logarithmic plots of the stress versus creep rate and rupture time for the alloys are shown in Figure 16. It can be seen that the lowest creep rate was exhibited by the binary alloy, and that the creep rates exhibited by the 2 and 3 w/o tin- or zirconium-containing materials are comparable.

TABLE 5. RUPTURE STRENGTH OF ALUMINUM-35 w/0 URANIUM ALLOYS CONTAINING TERNARY ADDITIONS OF TIN OR ZIRCONIUM AT $200 \mathrm{C}$

\begin{tabular}{lccc}
\hline & $\begin{array}{c}\text { Nominal Ternary Addition } \\
\text { (Balance Aluminum-35 w/0 } \\
\text { Uranium/, } / 0\end{array}$ & $\begin{array}{c}\text { Rupture Strength } \\
\text { at 200 C, psi }\end{array}$ \\
\cline { 3 - 4 } 105 & 2 tin & $100 \mathrm{Hr}$ & $1000 \mathrm{Hr}$ \\
106 & 3 tin & 8100 & 6900 \\
113 & None & 7100 & 6200 \\
117 & 2 zirconium & 9800 & 8300 \\
118 & 3 zirconium & 8600 & 7100 \\
122 & 2 zirconium & 7900 & 6800 \\
123 & 3 zirconium & 9000 & 7600 \\
& & 8700 & 7400 \\
\hline
\end{tabular}

(a) Heats 122 and 123 were vacuum melted; the others were air melted.

\section{CONCLUSIONS}

From the above studies it was possible to conclude that the benefits to be gained by the additions of tin or zirconium were the result of their ability to inhibit the UAl3-to$\mathrm{UAl}_{4}$ transformation and to reduce the compound particle size. The improved properties imparted to the alloys are listed on page 28. 
Rupture Time, hr
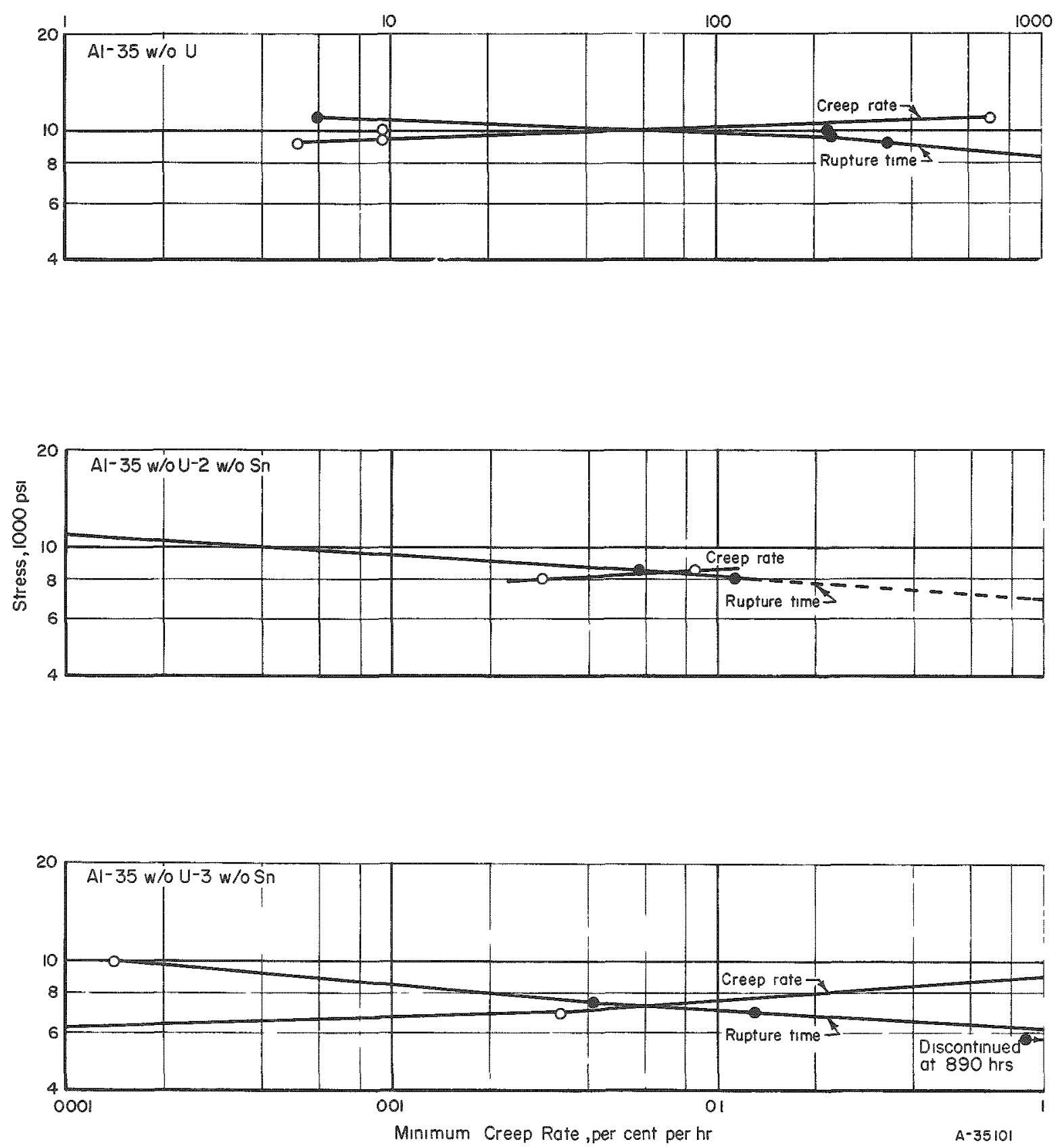

FIGURE 16. EFFECT OF TIN AND ZIRCONIUM TERNARY ADDITIONS ON THE CREEP-RUPTURE BEHAVIOR OF THE ALUMINUM-35 w/0 URANIUM ALLOY AT 200 C 
Rupture Tume, hr
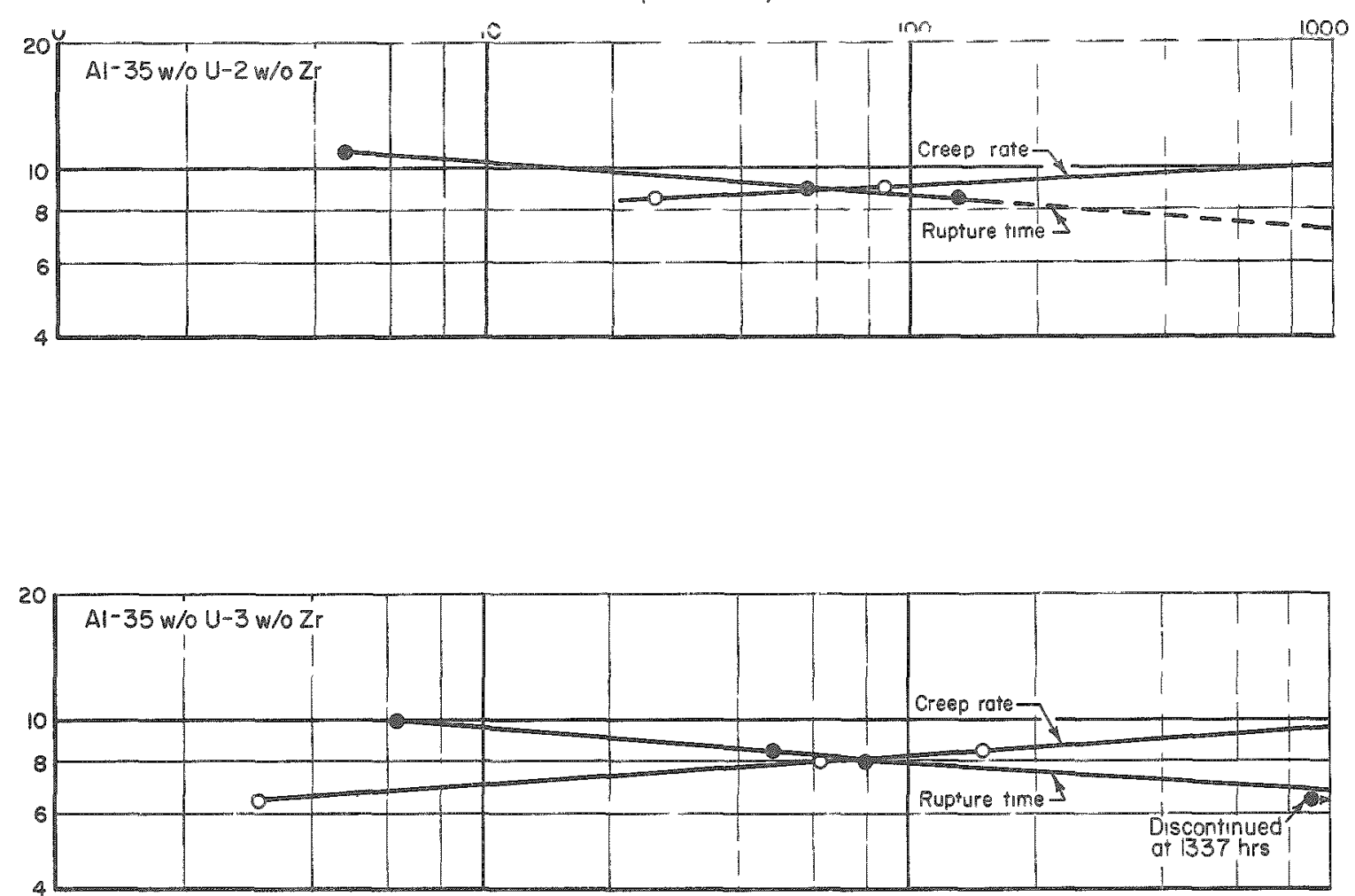

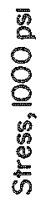
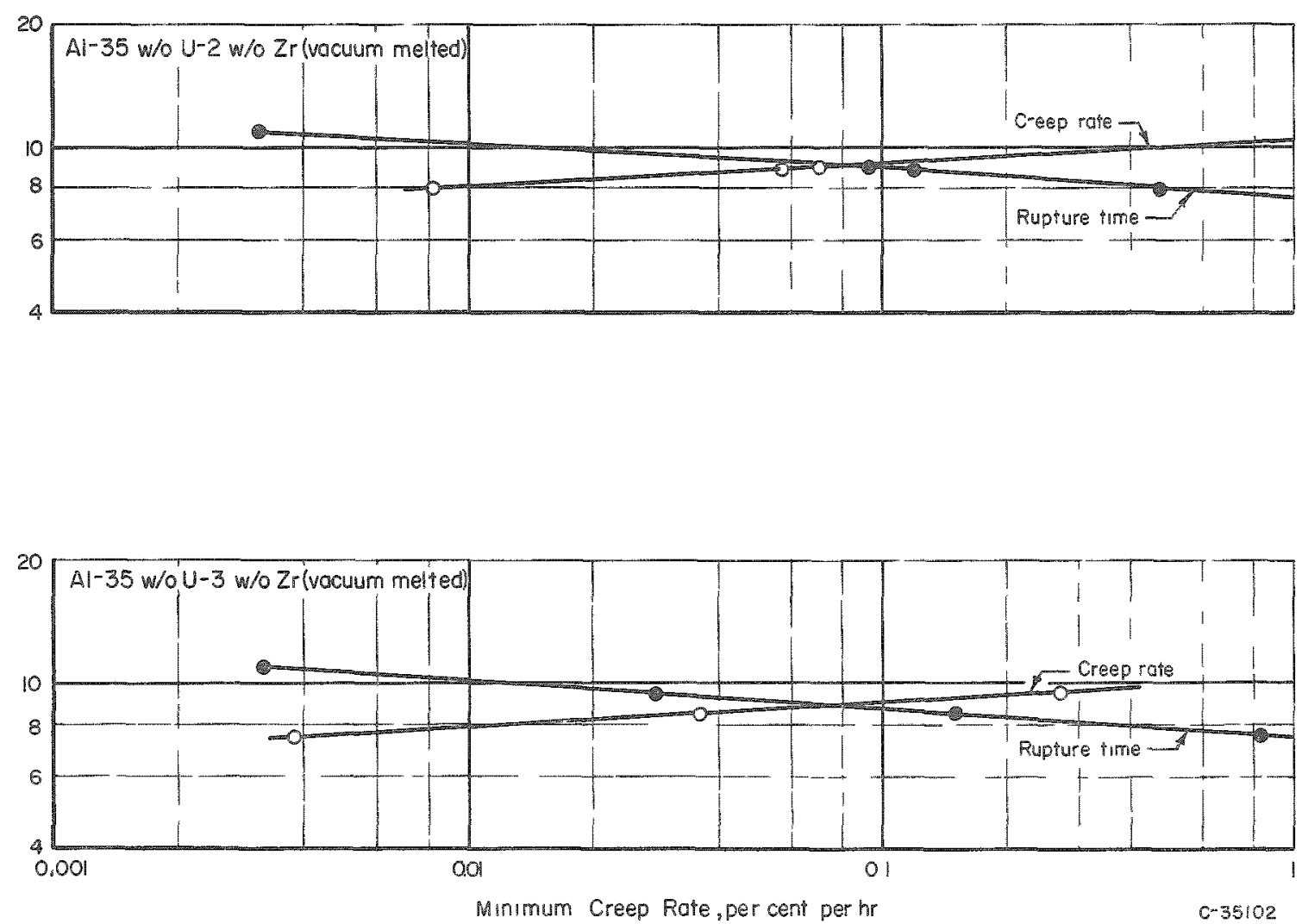
(1) Tin increases the fluidity of the aluminum-35w/o uranium alloy.

(2) Alloys containing either tin or zirconium in quantities of 2 to $3 \mathrm{w} / 0$ exhibited less gravitational segregation than did the binary aluminum$35 \mathrm{w} / \mathrm{o}$ uranium alloy. The least segregation was exhibited by the $3 \mathrm{w} / 0$ tin alloy.

(3) Hot-hardness determinations at temperatures up to $600 \mathrm{C}$ showed that the additions lowered the hardness.

(4) Airmmelted alloys containing tin or zirconium required less pressures for extrusion at $800 \mathrm{~F}$ than did the airmelted binary alloy. The finer structure in the vacuum-melted alloys resulted in increased extrusion pressures.

(5) There were no deleterious effects on the corrosion resistance of the alloys in $150 \mathrm{C}$ water attributable to the ternary additions.

From the above conclusions it can be stated that tin and zirconium are beneficial in that they improve the fabricability of aluminum- $35 \mathrm{w} / 0$ uranium alloys, and other studies have shown that they will decrease the gravitational segregation of said alloys. (3) The fact that the additions did not prove deleterious during corrosion tests means that one of the most attractive attributes of aluminum-uranium alloys is retained when the additions are made.

However, the above listed benefits are not obtained without a sacrifice in mechanical properties. The ternary alloys exhibited lower tensile strength than did the binary alloy and the creep properties were also lowered. While the decreased hardness and compound content of the ternary alloys make them attractive from the fabrication viewpoint, in applications where strength and creep properties are of prime importance the additions of tin or zirconium may be detrimental.

\section{REFERENCES}

(1) Epremian, E., "Nuclear Fuels Newsletter", WASH-703 (August, 1957).

(2) Thurber, W. C., and Beaver, R. J., "Development of Silicon-Modified 48 Wt \% U-Al Alloys for Aluminum Plate-Type Fuel Elements", ORNL-2602 (March 23, 1959).

(3) Daniel, N. E., Foster, E. L., and Dickerson, R. F., "Effects of Ternary Additions on Aluminum-35 w/o Uranium Alloys", BMI-1388 (October 27, 1959).

(4) "Tentative Recommended Practice for Conducting Creep and Time-for-Rupture Tension Tests of Materials", ASTM Standards, Part 3, Recommended Practice E 139-58 T (1958). 